\title{
Distal humerus kaynamamaları
}

\author{
Distal humerus non-unions
}

\author{
Kahraman Öztürk
}

Sağlık Bilimleri Üniversitesi, Baltalimanı Kemik Hastalıkları Eğitim ve Araştırma Hastanesi, El Cerrahisi Kliniği, İstanbul

İç tespit prensip ve tekniklerindeki ilerlemelere, uygulanan materyallerdeki gelişmelere rağmen, distal humerus kırıklarında kaynamama meydana gelmektedir. Kaynamama, cerrahi tespitin kurallara uygun yapılmadığı durumlarda, osteoporotik kırık ve parçalı kırıklarda görülmektedir. Distal humerusu kaynamayan olguların cerrahi hazırlık aşamasında enfeksiyon araştırılmalı; kemik stoğu, insizyonların yerleşimi, dolaşım ve nörolojik değerlendirme yapılmalıdır. Distal humerus kaynamama hattında, debridman, dizilimin düzeltilmesi, greftleme, gerekli olgularda kapsül gevşetmesi ve rijid tespit ile iyi sonuçlar elde edilmektedir.

Anahtar sözcükler: distal humerus; kaynamama; osteoporoz; rijid iç tespit; gevşetme
Despite of improvements in internal fixation techniques and fixation materials used, distal humerus nonunions were observed. In osteoporotic fractures, and comminuted fractures, non-unions were observed in conditions when fixation was not performed according to fixation principles. In distal humerus non-unions; infection, bone reserve, incision scars due to previous surgeries, circulation and neurological evaluations must be held preoperatively. Good results can be achieved in distal humerus non-unions after debridement, correction of the alignment, grafting, capsular release, and rigid internal fixation.

Key words: non-union; distal humerus; osteoporosis; rigid internal fixation; release
Y eni internal tespit prensipleri ve tekniklerinin ilerlemesi ile karmaşık distal humerus kırıklarının stabil tespitine ${ }^{[1]}$ rağmen günümüzde kaynamama distal humerus kırıklarının en önemli problemi olmaya devam etmektedir. Özellikle yaşlı hastalarda, karmaşık anatomi, kötü kemik kalitesi, çok parçalı kırık kombinasyonu başarılı bir tedaviyi zorlaştırmaktadır. Distal humerusta kaynamamanın en önemli nedeni ilk uygulanan cerrahi tespitin yetersiz yapılmış olmasıdır. ${ }^{[2,3]}$ Osteosentez sonrası implant yetersizliği ve kırı̆̆ın deplase olması cerrahiden sonraki birkaç ayda meydana gelir. ${ }^{[4]}$ Tedaviye dirençli kırık kaynamaması, çok sayıda geçirilmiş başarısız cerrahi, kötü kemik stoğu, enfeksiyon, sigara içimi ve şişmanlık ile birliktedir. ${ }^{[5]}$

Açık redüksiyon ve iç tespit ile tedavi edilen kırıkların yaklaşık olarak \%2-12'sinde kaynama gecikmesi veya kaynamama meydana gelir. ${ }^{[3,5,6]}$ Kaynamama $A O$ tip $C$ distal humerus kırıklarında daha sık görülür. ${ }^{[2,3]}$ Claessen, AO tip C distal humerus kırıklarında tespit gevşemesi, implant kırılması ve kaynamama nedeni ile 129 olgunun 16'sına yeniden cerrahi tedavi yapmış, teknik faktörlerden daha ziyade sigara içimi, şeker hastalığı ve şişmanlık gibi hasta ile ilgili faktörlerin önemli olduğunu vurgulamıştır. ${ }^{[3]}$ Kaynamayan distal humerus ağrı, kaynamama hattında dengesizlik, fonksiyon kaybı ve şekil bozukluğu ile birliktedir. Ayrıca, dirsekte kalıcı eklem sertliği, travma sonrası osteoartroz, ulnar nöropati, enfeksiyon ve işlevsel sakatlık, bu zorlu kırıkların cerrahi tedavisinin istenmeyen kötü sekelidir. Kaynamamaya eşlik eden tedavi süreci uzadıkça problem büyüyerek devam eder. ${ }^{[2,3,5,7]}$

Distal humerus kaynamaması sıklıkla suprakondiller seviyededir ${ }^{[2,5]}$; dış ve iç kondil, osteokondral ve epikondil kaynamaması da görülür. ${ }^{[7-10]}$ Kaynamama ile iç tespitin yetmezliği gelişir (Şekil 1). Osteopenik ve çoklu küçük eklem içi parçalı kırığı olan yaşlı hastaların kaynamayan kırık hattında hareket ile birlikte, sonunda materyaller yetmezliğe uğrar veya gevşer. Gevşeme ile birlikte kemik içinde vidaların cam sileceği hareketi,

- Illetişim adresi: Prof. Dr. Kahraman Öztürk, Kartaltepe Mah. Ömür Sok. No: 8/9, Bakırköy, İstanbul

Tel: 0532 - 4271798 e-posta: kahraman_ozturk@hotmail.com

- Geliș tarihi: 1 Kasım 2017 Kabul tarihi: 1 Kasım 2017 

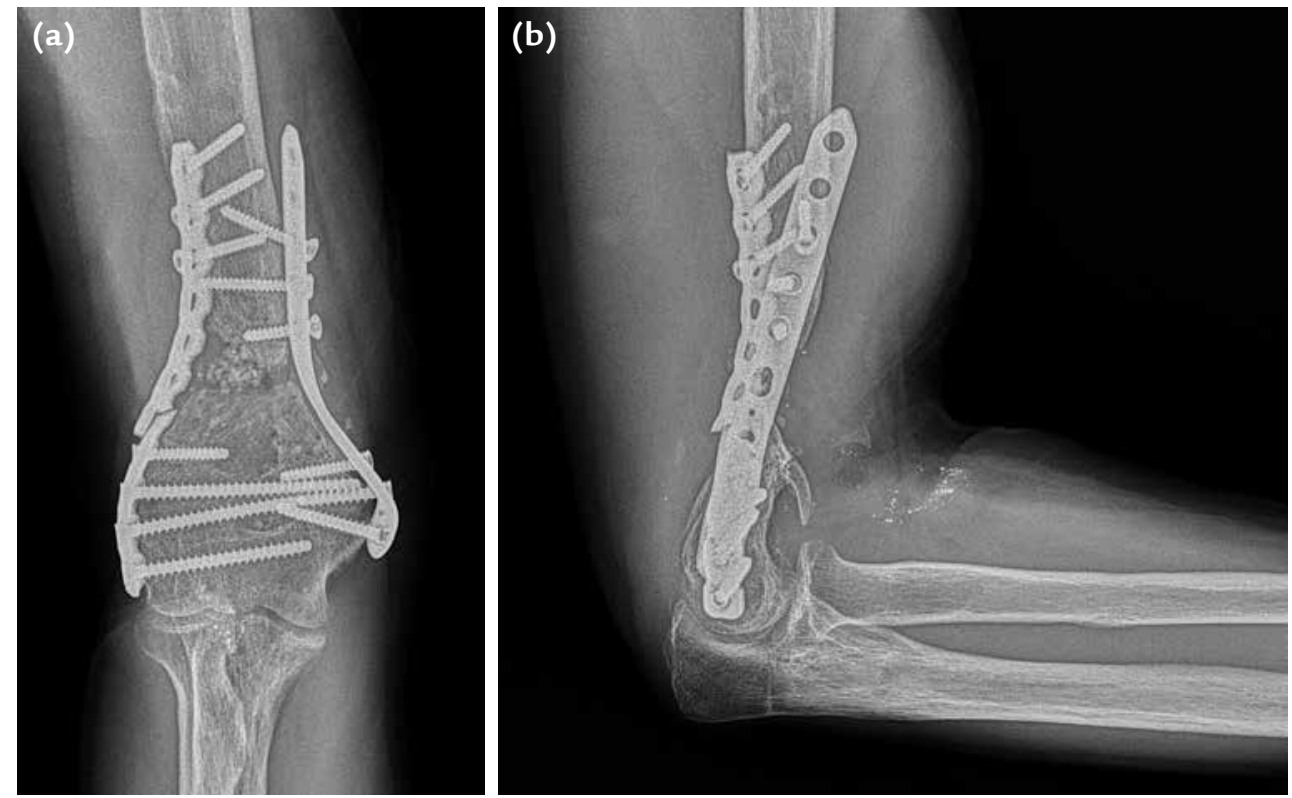

Şekil 1. a, b. Ateşli silah yaralanması sonrası suprakondiller kırık için osteosentez yapılan hastanın direkt ön-arka (a) ve yan (b) radyografisinde kaynamama nedeni ile dış kolona yerleştirilen plakta kırılma ve iç kolona yerleştirilen plak ve vidalarda gevşeme görülmektedir.
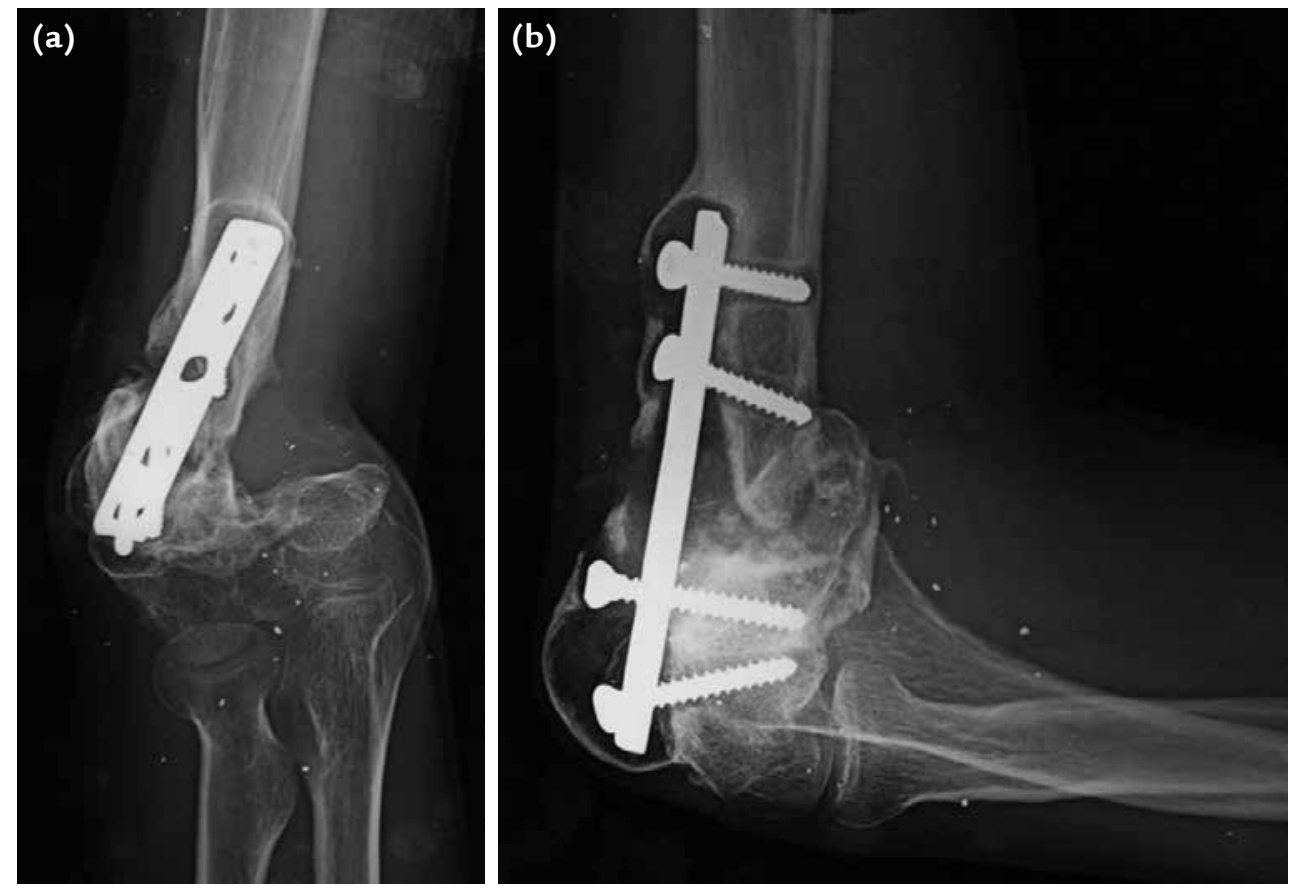

Şekil 2. a, b. Humerus distal uçta sekiz yıl içinde yapılan dört ameliyat sonunda kaynamaması devam eden olguda, plak ve vidaların gevşemesi ile birlikte kemik içinde vidaların cam sileceği hareketi ile vida çevresinde oluşan kistler ve kemik kaybı $(\mathbf{a}, \mathbf{b})$ görülmektedir.

kemik stoğunun daha fazla erimesine ve kistlere yol açar (Şekil 2). İmplant gevşemesi ve kemik kaybı olan hastalarda fleksiyon ve ekstansiyon hareketleri, çoğunlukla eklemden değil kaynamama hattından yapılır.
Kaynamayan distal humerus kırıklarının cerrahi tedavisi sonrası yine kaynamama, sert dirsek, heterotopik kemik oluşumu, ulnar sinir lezyonu ve implant irritasyonu görülebilir. ${ }^{[2]}$ 


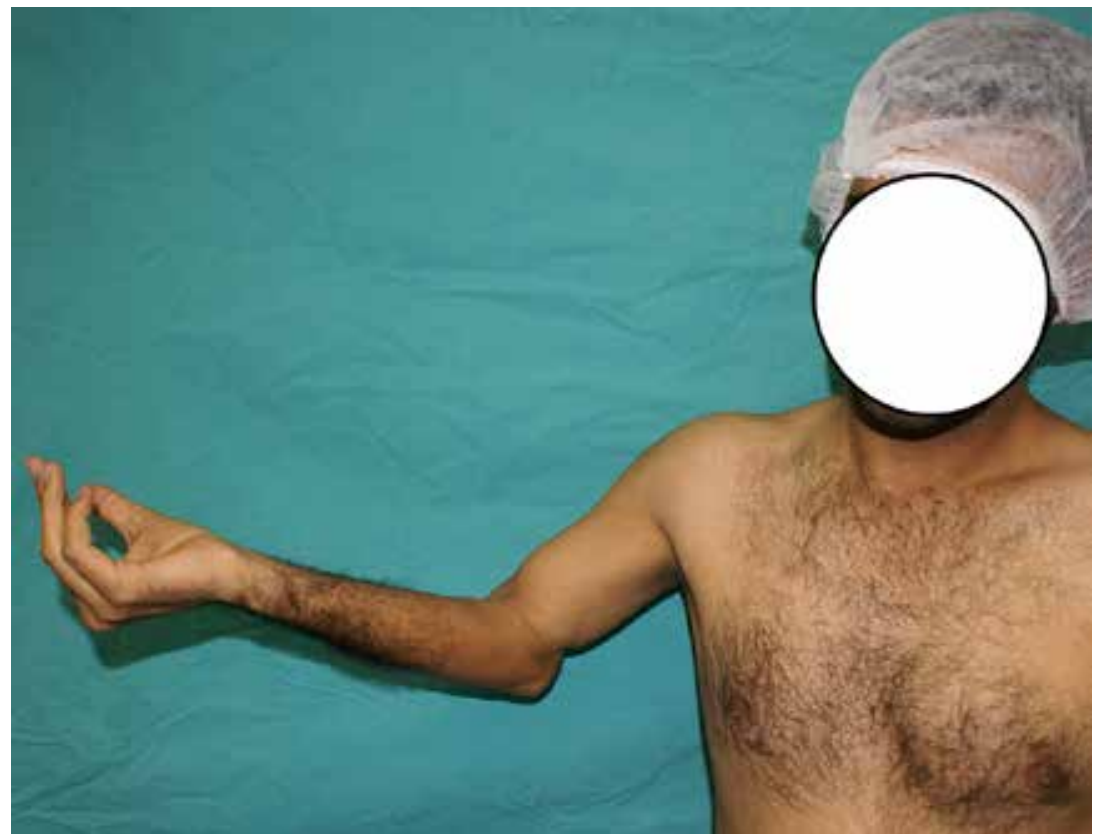

Şekil 3. İmplant gevşemesi ve kemik kaybı olan hastada fleksiyon ve ekstansiyon hareketi kaynamama hattından yapılmaktadır.

\section{ETIYOLOji}

Distal humerus kırıklarının tedavisinde, ciddi bir yumuşak doku yaralanması, osteopeni, ek hastalıklar, sigara kullanımı ve ameliyat sonrası hasta uyumu önemlidir. Humerus alt uç kırıklarında \%2-12 oranında kaynamama bildirilmiştir. En sık görülen, kırık redüksiyon kaybına bağı meydana gelen kaynamamada, kötü uygulanmış cerrahi teknik, uygun tespit materyalinin seçilmemiş olması veya her ikisinin bir arada bulunması etkendir. Açık kırıklar, çok parçalı kırıklar, yüksek enerjili yaralanmalar ve enfeksiyon, kaynamamaya yatkınlığı arttıran faktörlerdir. ${ }^{[2,3,5,6,11]}$ Distal humerus kaynamaması, az oranda da olsa tedavi edilmeyen kırıklar sonrası görülebilir. Cerrahi tedavi yapılmamış kırıklar$\mathrm{da}$, erken hareket kaynamamadan sorumludur. ${ }^{[12]}$

\section{FiziK MUAYENE}

Hasta ile ilk karşılaşmada; ilk kırık tarihi, açık kırık olup olmadığı, yumuşak doku girişimi, geçirdiği ameliyat sayısı ve notları sorgulanmalıdır. Hastada fleksiyonun dirsek ekleminden mi yoksa kaynamama alanından mı olduğu tespit edilmelidir. Kemik kaybı ile birlikte olan olgularda, el ve önkol yerçekimi karşısında desteklenemez (Şekil 3, Şekil 4. a, b, c). Enfeksiyon belirti ve bulguları sorgulanmalıdır. Muayenede yumuşak dokunun durumu, insizyon yer ve sayısı, eklem hareket açıklığı, ulnar sinir duyu ve fonksiyonu ile birlikte ekstremitenin damar sinir muayenesi yapılarak kayıt edilmeli ve resim çekilmelidir. Kaynamamaya yol açabilen sigara kullanımı ve kemik iyileşmesini önleyen ilaç kullanımı sorgulanmalıdır.

\section{RADYOLOJIK TETKIK}

Direkt ön arka ve yan radyografiler alınmalıdır. Direkt radyografide; kemik kalitesi, implant yerleşimi, distal ve proksimal parçanın durumu ve kaynamama yeri, kemik kaybı ve distal parçanın büyüklüğü değerlendirilir (Şekil 4. e, f). Ayrıca direkt radyografiler, kaynamama için osteosentez veya artroplasti kararı, kemik greft ihtiyacı ve osteosentez için kullanılacak implant seçimi için de yardımcı olur. Önceki cerrahi veya cerrahilere ait radyografilerde, ilk kırık şekli, kemik kayıp miktarı ve kullanılan implantlar ve kaynamama nedenleri değerlendirilir.

Standart ön-arka ve yan radyografiler distal parçanın gerçek boyutları konusunda yanıltıcı olabilir. Distal parçanın büyüklüğü, fleksiyonda çekilmiş ön-arka radyografide olduğundan daha küçük olarak değerlendirilebilir. Traksiyon radyografileri distal parça büyüklügüü hakkında yararlı olabilir. Üç boyutlu rekonstrüksiyon ile birlikte bilgisayarlı tomografi (BT), kemik stok ve distal parçanın büyüklüğü, plak ve vida yerleşimi için planlama ve greft konulacak alan seçiminde çok yardımcı olur (Şekil 4. f, g, h). ${ }^{[7]}$ 

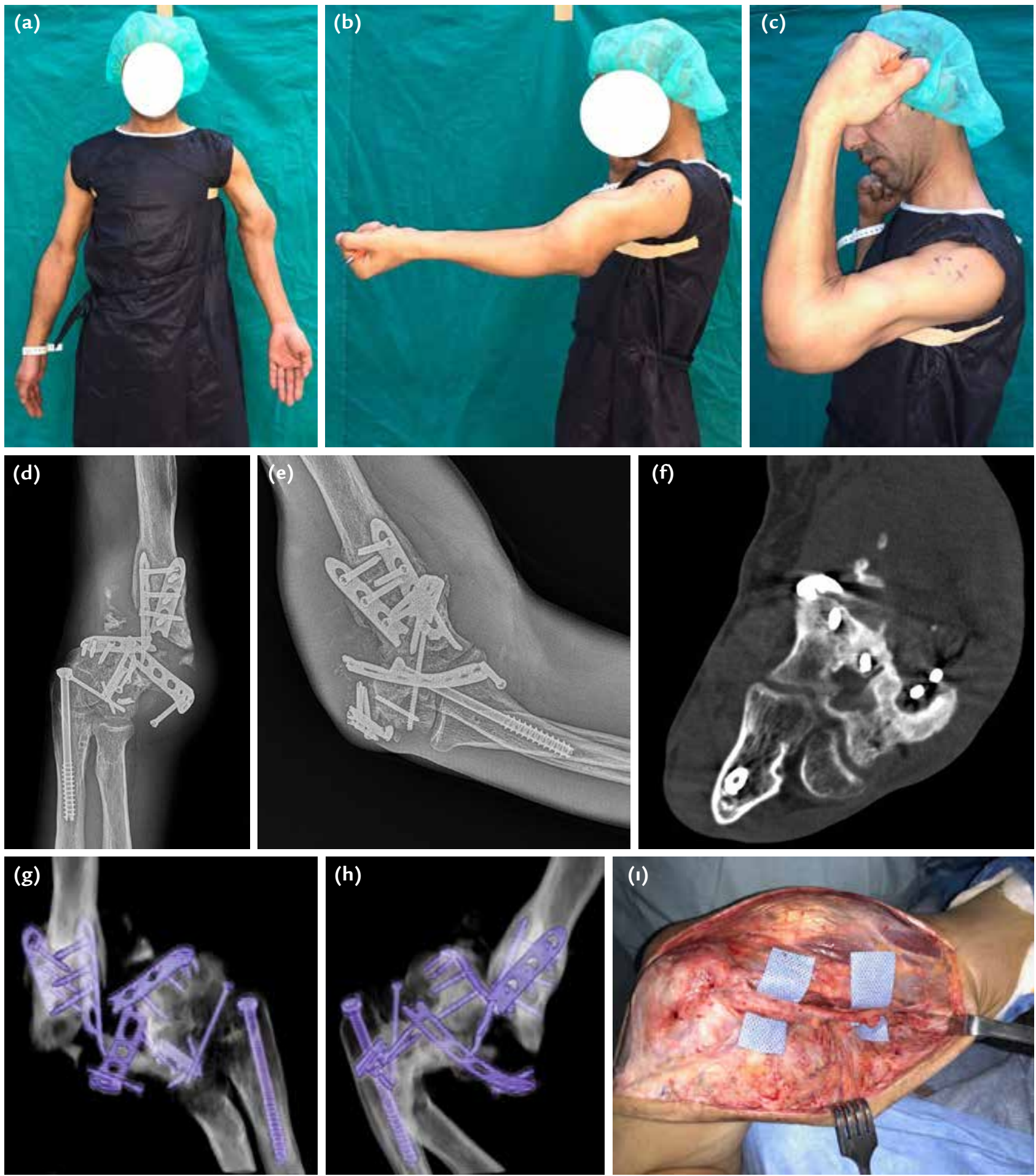

Şekil 4. a-ı. Otuz altı yaşındaki erkek hasta dört yıl önce 6 metre yüksekten düşme sonrası üç kez ameliyat geçirmiş. Hasta son ameliyatını iki yıl önce olmuş. Sol üst ekstremitede kısalık ve şekil bozukluğu ile birlikte sert dirsek olan olguda, fleksiyon ve ekstansiyon hareketi kaynamama hattından (a, b, c) yapılmaktadır. Ön arka ve yan direkt radyografilerinde kaynamama hattında iç ve dış kolonda iki plağın da kırıldığı ve kırık plak ile vidaların serbest kaldığı (d, e), olgunun BT'sinde ulnotroklear ve radyokapitellar eklemin korunduğu (f) görülmektedir. Üç boyutlu tomografide; kaynamama hattı, serbest kalan kırık plaklar ve vidaların distal humerustaki yerleşimi $(\mathbf{g}, \mathbf{h})$ görülmektedir. Humerus distal uçta arka yüzden yapılan insizyon sonrası, distale gittikçe basıya bağlı olarak kalınlaştığı izlenen ulnar sinir serbestleştirilmiştir (।). 

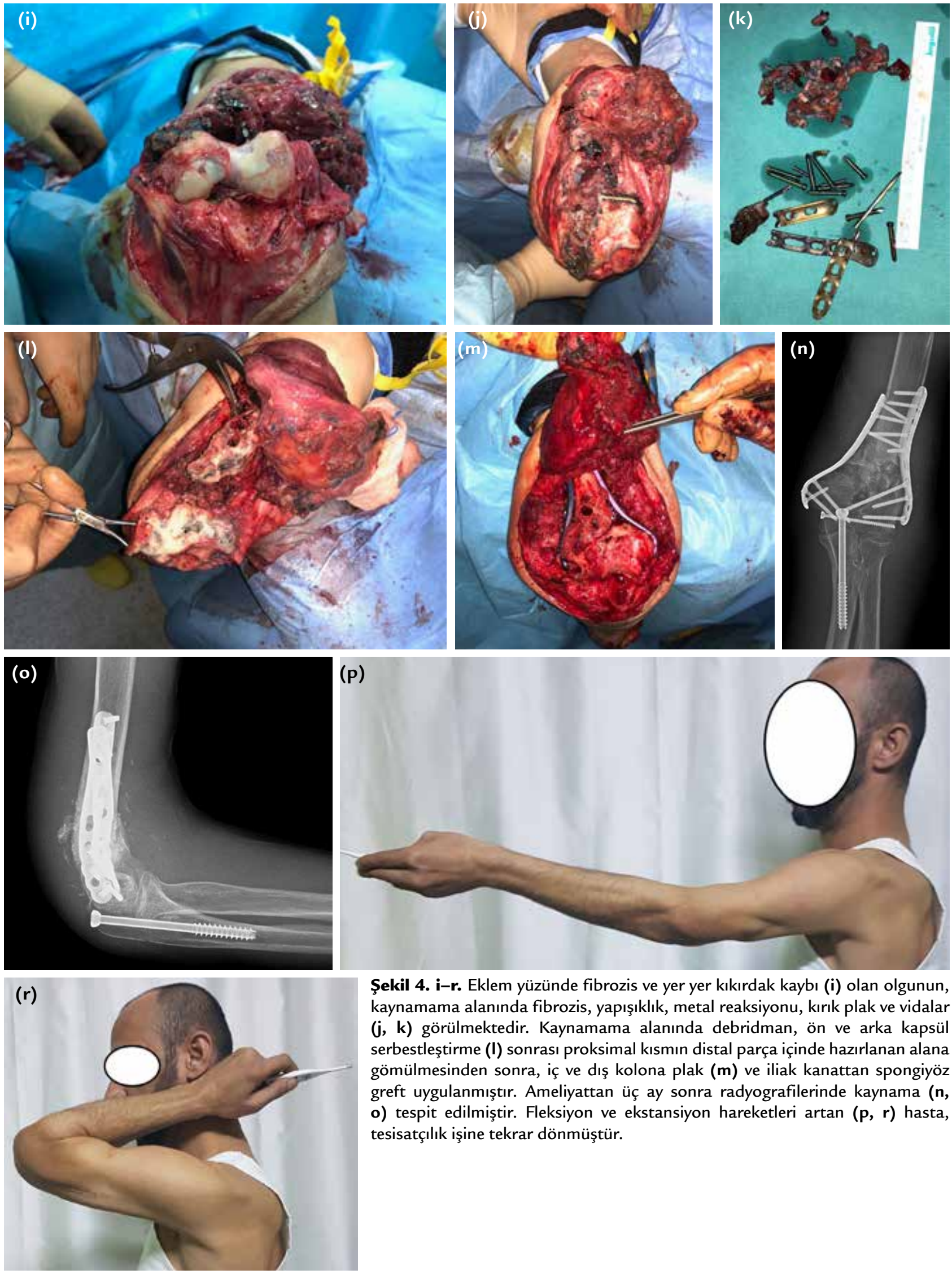

Şekil 4. i-r. Eklem yüzünde fibrozis ve yer yer kıkırdak kaybı (i) olan olgunun, kaynamama alanında fibrozis, yapışıklık, metal reaksiyonu, kırık plak ve vidalar (j, k) görülmektedir. Kaynamama alanında debridman, ön ve arka kapsül serbestleştirme (I) sonrası proksimal kısmın distal parça içinde hazırlanan alana gömülmesinden sonra, iç ve diş kolona plak $(m)$ ve iliak kanattan spongiyöz greft uygulanmıştır. Ameliyattan üç ay sonra radyografilerinde kaynama (n, o) tespit edilmiştir. Fleksiyon ve ekstansiyon hareketleri artan $(p, r)$ hasta, tesisatçılık işine tekrar dönmüştür. 


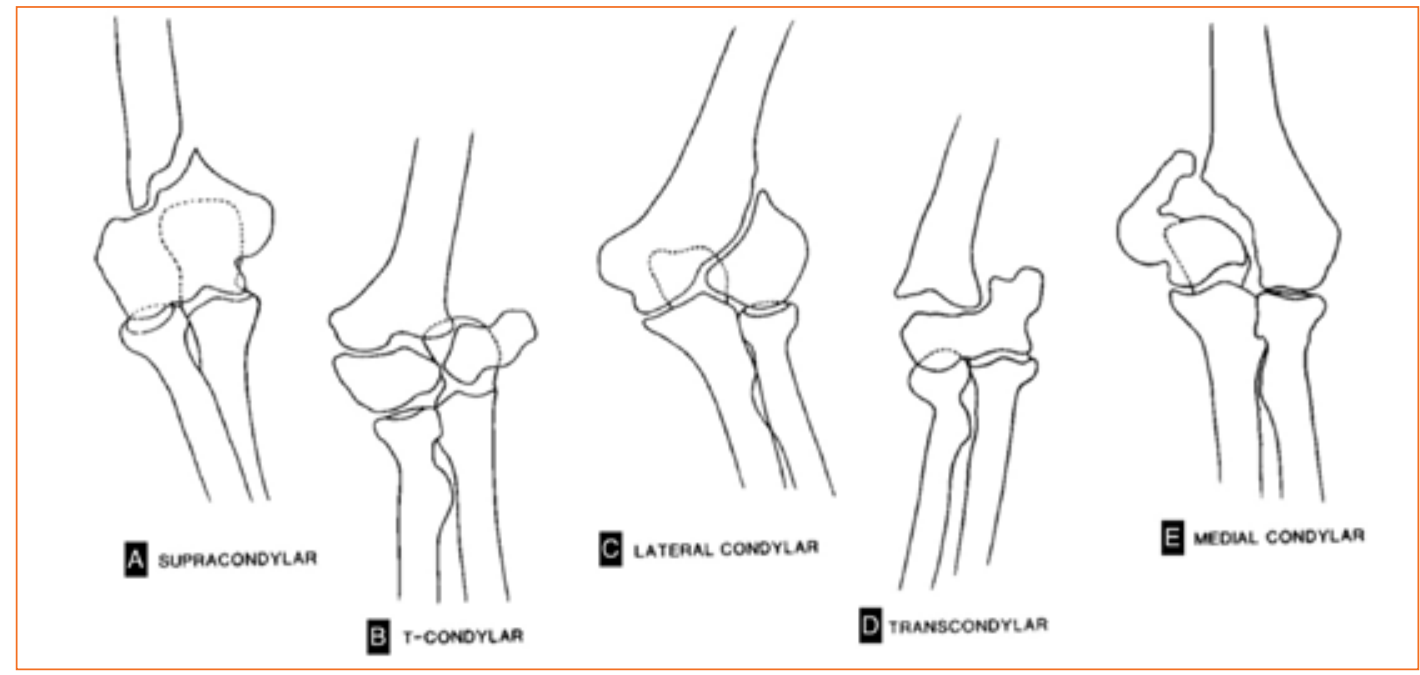

Şekil 5. Distal humerus kaynamaması için Mitsunaga sınıflaması: (A) suprakondiller, (B) T-kondiller, (C) lateral kondiller, (D) transkondiller ve (E) mediyal kondiller. ${ }^{[16]}$

\section{LABORATUVAR INCELEMESI}

Distal humerus kaynamaması olan her hasta, geçirmiş olduğu cerrahiler ve enfeksiyon açısından sorgulanmalıdır. Dirsekte akıntı, sinus ağzı ve ciltte ısı artışı ve hiperemi gibi enfeksiyon bulguları muayenede değerlendirilir. Enfeksiyon araştırması için tam kan sayı$\mathrm{m}$, sedimantasyon yüksekliği ve CRP (C-reaktif protein) değerlerine bakılmalıdır. Bu değerlerde yükselme, enfeksiyon ihtimalini akla getirmelidir. ${ }^{[5,13]}$ Humerusta kaynamayan alan ve dirsek ekleminden aspirasyon gerekirse, ultrasonografi veya BT altında yapılmalıdır. ideal olarak, hastalar antibiyotik kullanmayı aspirasyondan 2 ila 4 hafta önce kesmelidir. Alınan aspirasyon örnekleri hücre sayımı, gram boyama, kültür ve antibiyogram için laboratuvara gönderilmelidir. ${ }^{[14]}$

\section{SINIFLAMA}

Distal humerusun kaynamaması, sıklıkla azalmış biyolojik aktivite ve yetersiz stabilitenin kombinasyonu olarak oligotrofiktir. ${ }^{[15,16]}$ Humerus distalinde kaynamama, suprakondiller, transkondiller, interkondiller, unikondiller (mediyal veya lateral) veya osteokondral olarak alt sınıflara ayrılabilir. ${ }^{[15,16]}$ Mitsunaga, distal humerusta kaynamamayı ön-arka ve yan radyografilere göre; suprakondiller, T-kondiller, lateral kondiller, transkondiller ve mediyal kondiller olarak sınıflamıştır (Şekil 5). Suprakondiller ve aşağı transkondiller kaynamama arasındaki ayrım, kaynamamanın olekranon fossa proksimal kenarının, proksimal veya distal olan yerleşme konumuna dayalıdır. ${ }^{[16]}$ Distal humerus kaynamaması önemli oranda eklem parçalarının anatomiye yakın iyileştiği suprakondiller seviyededir. ${ }^{[7,13]}$

\section{TEDAVi}

Cerrahi tedavinin planlanmasında, yaş, tıbbi durum, önceki cerrahi ve insizyon skarları, yeterli bir yumuşak doku örtümü ve diğer üst ekstremite engellerinin varlığı gibi hasta faktörleri göz önünde bulundurulmalıdır. ${ }^{[11]}$

Kaynamayan humerus distal uçta; açık redüksiyon internal tespit ve gerekirse greftleme ${ }^{[2,3,13]}$, protez replasman ${ }^{[17]}$, allogreft ile dirsek replasman ${ }^{[18]}$, dirsek artrodezi ${ }^{[11]}$, distraksiyon artroplastisi ${ }^{[19]}$, Ilizarov tekniği ile osteosentez ${ }^{[20]}$ tedavileri uygulanabilir. Kondi[ ${ }^{[9]}$ ve epikondil kaynamamasında ise açık redüksiyon internal tespit ve gerekirse greftleme yapılabilir. Yine epikondil kaynamamasında, parça eksizyonu ve kas grubunun anatomik yerine sütür ile tespiti ve iç kollateral bağ rekonstrüksiyonu yapılabilir.

Humerus alt uçta kaynamama için yapılan tedavilerin her birinin; kemik füzyonunun güçlüğü (kısıtlı kemik stoğundan dolayı), instabilite, güçsüzlük ve dirsek eklemi işlevinin kaybı, nöropatik eklemler ve enfeksiyon gibi kısıtlamaları ve komplikasyonları mevcuttur. ${ }^{[13]}$ Hastanın yumuşak doku örtümü ve lokal ve serbest flep gerekliliği değerlendirilmelidir.

\section{Enfeksiyonla birlikte olan kaynamamalar}

Eklem içi kırıklarda internal tespitin enfeksiyon nedeni ile başarısızlı̆ğıda, hem implantlar çıkarılarak debridmanla birlikte enfeksiyon eradikasyonu yapılmalı hem de eklem yüzeyi düzeltilerek fonksiyonları arttırmak için kırık iyileştirilmelidir. ${ }^{[7]}$ Antibiyotik emdirilmiş sement uygulaması, lokal yüksek doz antibiyotik salınmasını sağlar. Ciddi kemik kaybı veya yumuşak dokusu kötü olan olgulara geçici eksternal fiksatör uygulanabilir. ${ }^{[5,13,20]}$ 
Kültür ve antibiyograma uygun antibiyotik altı hafta süre ile damar yolu ile verilir. Antibiyotik tedavisi kesildikten iki ve dört hafta sonra aspirasyon tekrarlanır. ${ }^{14]}$ Enfeksiyonu tedavi edilen olgular, kapsülektomi, ulnar sinirin transpozisyonu veya nörolizi, uygunsa kemik greftlemesi ve stabil tespit ile tedavi edilebilir. Eklem dışı kaynamamalarda, kemik defekti büyük ise damarı kemik greftleri ile rekonstrüksiyon yapilır. Eklemi kötü olan genç olgulara implant artroplastisi önerilmediği için, dirsek artrodezi yapılabilir.

Brinker, açık redüksiyon ve iç tespit ile ortalama 2,8 defa (1-4 kez) ameliyat edilen altı hastayı ilk yaralanmadan ortalama 27 ay (6-99 ay) sonra ameliyat etmiştir. Hastaları, tek aşamalı debridman, tespit materyallerinin çıkarılması, ulnar sinir gevşetilmesi, otojen kemik greftlemesi ve llizarov ile akut ve tedrici kompresyon yaparak tedavi etmiştir. Tüm olgularda kaynama meydana gelmiştir. Fiksatör çıkarıldıktan üç hafta sonra düşme ile kırık meydana gelen bir olguya total dirsek artroplastisi yapmıştır. ${ }^{20]}$

\section{Açık Redüksiyon ve İç Tespit}

Humerus distal uç kaynamamalarında başarılı bir osteosentez elde edilmesi için, kemik stoğu yeterli, eklem dejenerasyonu az ve kolay düzeltilebilen bir eklem kontraktürü olmalıdır. ${ }^{[1]]}$ Distal humerusu kaynamayan olgularda en sık olarak; debridman, eklem gevşetilmesi, ulnar sinir gevşetme, açık redüksiyon ve plak ile tespit ve gerekirse greftleme uygulanmaktadır. ${ }^{[2,5,16]}$ Gereken durumlarda humerusa kısaltma yapılabilir. ${ }^{[14]}$ Uygulanan tedaviler ile, ortalama altı ayda \%95 ve üzerinde kaynama elde edilir. ${ }^{[2,5,16]}$ Rekonstrüksiyon planlanırken, kapsüler kontraktür nedeni ile distal parçanın fleksiyona gitmesi olduğundan küçük olarak değerlendirilmesine yol açar. Sinoviyal psödoartrozda, kaynamamanın her iki tarafındaki reaktif sklerozis, erozyon ve özellikle distal parçada oluşan kemik rezorpsiyonu kemik anatomisini bozar ve instabil kaynamamaya yol açar. ${ }^{[21]}$ Ali, açık redüksiyon, plak tespiti ve greftleme ile, distal humerusu kaynamayan 16 olgunun 15'inde kaynama elde etmiştir. On beş olgunun birinde, enfeksiyon nedeni ile yeniden greftleme ile kaynama sağlamıştır. Mayo dirsek performans skoruna göre; 11 olguda mükemmel, iki olguda iyi, iki olguda orta ve bir olguda da kötü sonuç elde etmiştir. Olgularında ortalama $96^{\circ}\left(45^{\circ}\right.$ ila $\left.130^{\circ}\right)$ hareket açıklığı sağlamıştır. ${ }^{[2]}$

Açık redüksiyon ve iç tespit ve greftleme yapılan olgularda plak çıkarılması, ulnar sinir serbestleştirme ve dirsek sertliği için eklem gevşetmesi yapılması gerekebilir. Olgularda yine enfeksiyon ve kaynamama görülebilir. ${ }^{[2,5]}$ Helfet ve Rosen, 27'si kaynamama ve diğerleri kaynama gecikmesi olan 27 suprakondiller, 6 transkondiller, 13 T-kondiller veya kondiller arası, 2 dış kondil ve 4 iç kondil seviyesinde distal humerus kaynamaması olan 52 hastayı tedavi etmiştir. Sekiz hastada komplikasyon görülmesine rağmen (dördünde ameliyat sonrası ulnar nöropati, ikisinde radyal sinir disfonksiyonu, ikisinde enfeksiyon ve birinde kompartman sendromu), kaynamama olan 27 hastanın tamamında kaynama elde edilmiştir. Ortalama altı ayda (2-24 ay) kaynama elde ettiği olgularında hareket açıklığı $71^{\circ}$ 'den $94^{\circ}$ 'ye çıkmıştır. Hastaların \%30'unda, hareketi arttırmak, ulnar sinir sorunlarını çözmek veya dışarıdan belirgin implantları çıkarmak amacıyla ek cerrahiler gerekmiştir..$^{[5]}$ Mayo klinikten Sanchez-Sotelo, aşağı seviyede distal humerus kaynamaması ve ciddi kemik kaybı olan 12 olguyu, humerusa kısaltma, kapsüler gevşetme, greftleme ve paralel plak uygulaması ile tedavi etmiştir. Kaynama elde ettiği ve ağrı olmayan tüm olgularda ortalama $113^{\circ}$ fleksiyon ve $22^{\circ}$ ekstansiyon hareketi sağlamıştır. Kaynama sonrası eklemde çökme meydana gelen iki olguya total dirsek artroplastisi yapmıştır. Bir olguda, derin enfeksiyon ve heterotopik kemikleşme nedeni ile revizyon cerrahisi uygulamıştır. ${ }^{[14]}$

Humerus alt uç kaynamama alanında, olekranon osteotomisi ile birlikte geniş bir açılım yapılır. Olekranon trokleadan dikkatli bir şekilde ayırılmalıdır. Eski olgularda, troklea ile olekranon arasında oluşabilecek fibrozis yapışıklığa yol açabilir. Fibrozis, olekranon kaldırılırken troklea hiyalin kıkırdağının subkondral kemikle birlikte ayrılmasına yol açar. Bunu engellemek için, olekranon küçük alet ve ince hareketlerle yavaş bir şekilde trokleadan ayırılmalıdır. ${ }^{[7]}$

Stabil internal tespit elde edilmesi, distal parçanın büyüklüğ̈̈, osteoporoz varlığı ve elde bulunan implantların özelliğine göre önemli ölçüde değişir. ${ }^{[7]}$ Sanders, implant seçimi ve implant yerleşiminin önemine vurgu yapmıştır. Humerusta dış kolon, iç kolondan daha geniş olduğu için ilk tespite radyal kolondan başlanmasını önermektedir. Rijid plağın uygulaması, humerusun radyal kolonu üzerinde sagittal planda olmalıdır. Bu yerleştirme iki korteks tespitine izin verir ve distal humerusta varus-valgus streslerine olan direncin artmasını sağlar. Dış kolondan iç kolona uzun bir vida gönderilmesi kuvvetli bir tespit sağlar. İç taraftan uygulanan plak, distal humerusta varus-valgus eğilme kuwetlerine karşı direncin artmasını sağlar. ${ }^{[22]}$ Yeni tasarlanan implantlar, daha küçük parçaların stabil tespitine imkan sağlamaktadır.

Kaynamayan humerus alt uç kırıklarının çoğunda uygulanan açık redüksiyon ve iç tespitte hedefler; 1) iyi bir redüksiyon ve stabil internal tespit, 2) kemik aşısı veya kemik yerine kullanılan materyaller ile kemik iyileşmesinin uyarılması, 3) eşlik eden eklem kontraktürünün gevşetilmesi [tespit üzerine binen stresi azaltmaya ve eklem hareket açıklığını arttırmaya yardım eder] ve 4) ulnar sinirin korunmasıdır. ${ }^{[14]}$ 


\section{Cerrahi Teknik}

\section{Hazırlık ve pozisyon}

Hastaya yüzüstü veya yan yatar halde pozisyon verilir. Kondil veya epikondil kaynamamasında dış veya iç yandan giriş veya osteokondral makaslama tipi lezyonda dış yandan yaklaşım kullanılabilir. Cerrahi taktiği özetleyen ameliyat öncesi çizim, ameliyat içi sorunların öngörülmesi ve önlenmesine yardımcı olabilir. Hastaların çoğunda önceden yapılmış olan posterior orta hat insizyonu kullanılabilir. Posterior insizyon, mediyal ve lateral fleplerin kaldırılması, ulnar sinir gevşetme ve olekranon osteotomisine izin verir. Ulnar sinir, dirsek yönünde fleksör karpi ulnarise verdiği ilk dala kadar ve proksimalde yeterli uzunlukta ortaya konur (Şekil 4. 1). Ameliyat öncesi ulnar sinir lezyonu varsa eksternal nöroliz yapilır. Olekranon osteotomisi, eklem içi, transkondiller ve aşağı uç distal humerusun kaynamadığı olgularda oldukça iyi bir görüş alanı sağlar. Distal humerusun suprakondiller bölgede kaynamadığı olgularda, trisepsi yarma (triceps splitting), triseps etrafından yaklaşım (paratricipital approach) ve trisepsi ankoneus ile birlikte kaldıran yaklaşım kullanılabilir. Ulnada, semilunar notch'ta kıkırdağın ince olduğu alanda Chevron osteotomisi yapılır. Proksimal parçaların dikkatli elevasyonu, olekranon kıkırdağının troklea üzerine yapışmasının sonucu olabilen eklem kıkırdak ayrışmasını önler (Şekil 4. i). Triseps, parmak disseksiyonu ve periost sıyırıc ile yukarı doğru 10 $\mathrm{cm}$ kaldırılır. Radyal sinir ve eşlik eden damarlara dikkat edilmelidir. Metal debrisler ve implantlar çıkarılır. Kırık parçaların anatomik redüksiyonunu engelleyen, araya giren skar dokuları ve kemik çıkarılır. (Şekil 4. j, k) Kültür ve patoloji örnekleri alınır. Proksimal ve distalde ön ve arka kapsül çıkarılır (Şekil 4. I). Eklem kıkırdağı ve eklem hareketi değerlendirilir. Hala eklem hareket açıklı̆ı tam olarak sağlanamıyorsa, dış yan kollateral bağ ve ekstansör orijini dış epikondil ostetomisi ile tam olarak veya bir kısmı dış epikondilde bırakılarak kaldırılır. İç yan kollateral bağ üzerinde menteşeli eklem hareketi ile, eklem keskin disseksiyonla debride edilerek serbestleştirilir. Daha sonra dış yan kollateral bağ ve ekstansör orijin yerine kemikten geçen sütür, çapa sütür veya dış epikondil ile birlikte osteotomi ile kaldırılmışsa vida ile tespit edilir. Kaynamayan kırık parçaların dolaşımının bozulmasını önlemek için aşırı debridmandan kaçınılmalıdır.

\section{Tespit}

Proksimal ve distalde kanama görülünceye kadar korteks alınır ve dril ile medulla oyulur. Eklemi içeren distal parça küçük ise medüller kanal açılmaz. Kemikte 2 mm'lik dril ile birkaç delik açılır. Kaynamamanın eklem içi komponenti varsa, önce kondiller birbirine Kirschner teli (K-teli) ile tespit edilerek eklem anatomisi sağlanır. Kondillerin hareketi kısıtlayan yanlış kaynaması durumunda, eklem içi osteotomi ile eklem anatomisi düzenlenir. Yeniden düzenlenen humeral kondilin trokleayı daraltmamasına dikkat edilmelidir. Kondiller blok, plak yerleşmesine engel olmayacak şekilde 1,6-2 mm'lik çapraz K-telleri ile humerus şaftına geçici olarak tespit edilir. Anatomi bozulduğunda yeniden dizilim ve stabil redüksiyon, şaftın içine distal parçanın impakte edildiği bir çentik oluşturularak sağlanabilir. Distal kısmın proksimal parça ile ilişkisi ve taşıma açısı ön-arka planda; kondil fleksiyon restorasyonu ise yan planda gözlem ve floroskopi değerlendirilir. Arka-ön planda taşıma açısı ve dış yan planda kondil fleksiyonu floroskopi ile değerlendirilir. Kilitli plak iç ve dış kolona yerleştirilir. Pozisyonu iyi olan olgularda metafiz ve şafta $3,5 \mathrm{~mm}$ vida ve eklem çevresine 2,7 $\mathrm{mm}$ kilitli vida uygulanır. Tespit stabilitesini azami hale getirmek için, distalden plak içerisinden içten dışa ve dıştan içe çaprazlayan iki uzun vida koymak tercih edilebilir (Şekil 4. m). Bazen, kolay drillemeyi önleyen vida kalabalığı vardır. Osilasyon dril modunda iken dril sıklıkla yolunu bulur. Sonraki çapraz vidalar, vidaların tutma gücünü arttıracaktır. Distal parçaya fazla vida atılamazsa, tespit stabilitesini arttırmak için üçüncü bir plak uygulanabilir. İhtiyaç varsa, iliak kanattan spongiyöz otogreft kaynamayan alana yerleştirilir. Olekranon, osteotomi hattında yerine yerleştirilir ve sekiz şeklinde tansiyon bandı veya olekranon plağı ile tespit edilir (Şekil 4. n, o). Ameliyat öncesi ulnar sinir semptom ve bulguları varsa, ulnar sinir öne transfer edilir. Ödem ve ağrı kontrolü için, kısa süreli alçı atel, ameliyat öncesi kontraktür yönüne uygun pozisyonda uygulanır. Kol baş üstü kaldırılarak zorlamasız aktif egzersizlere başlanır. Kaynama elde edildikten sonra zorlayıcı aktivitelere izin verilir (Şekil 4. p, r). ${ }^{[5,7,13,14]}$

\section{Büyük kemik defektlerinde damarlı kemik uygulaması}

Distal humerus kırıklarında, kırık anında parçalanmaya veya geçirilen başarısız cerrahi tedavilere bağı olarak segmental kemik kaybı meydana gelir. Bu olgularda; dirseğin anatomik kısıtlılıkları, büyük kemik kaybı ve önceki cerrahi işlemler nedeniyle stabil cerrahi tespiti sağlamak zordur. Geçirilmiş enfeksiyon da, damarlı olmayan kemik grefti ve artroplasti gibi çözümlerin kullanımını sınırlamaktadır. Damarlı kemik ile greftleme, genç ve humerus distal 1/3'te kemik kaybı ile birlikte olan, tedaviye cevap vermeyen inatçı kırık kaynamamalarının tedavisinde önemli bir seçenektir.

Damarlı kemik greftleri, kısmi kemik kaybı ile birlikte olan distal humerusta kaynamama alanında canlı kortikal kemik ile yapısal destek sağlar. Bu greftler, geleneksel greftleme tekniğine göre canlı kemik hücrelerinin kırık iyileşmesini aktive etmesi nedeni ile, kaynama sağlanmasında daha avantajıdır. ${ }^{[23]}$ Debridman, kontraktür 
gevşetilmesi damarlı fibula grefti ve plak uygulaması ile iyi sonuçlar bildirilmiştir. ${ }^{[7,23]}$ Beredjiklian, enfeksiyona bağlı ciddi kemik kaybı ile birlikte olan ve ortalama 3,4 kez ameliyat geçiren beş olgunun dördünde 4,5 ayda kaynama ve $94^{\circ}$ eklem hareket açıklığı elde etmiştir. Eklemde çökme meydana gelen bir olguda ise total dirsek protezi uygulamıştır (Şekil 6). ${ }^{[23]}$

\section{Distal humerus kondil kaynamaması}

Distal humerus kondil kaynamaması oldukça az görülür. Dış kondil kaynamamasına göre iç kondil kaynamaması daha nadir görülür. Erişkin yaşta görülen kondil kaynamaması daha çok çocukluk çağında geçirilmiş olan dış kondil kırığının kaynamamasıdır (Şekil 5). ${ }^{24]}$

Distal humerusta çocukluk çağında geçirilmiş dış kondil kaynamaması ile birlikte olan hastalarda, erişkin yaşta dirsekte ağrı, instabilite, ilerleyici kubitus valgus deformitesi ile birlikte ortaya çıkan geç ulnar sinir nöropatisi vardır. Şekil bozukluğu, hastalarda genellikle şikayete yol açmamaktadır. ${ }^{[24]}$ Hastalar, geç dönemde başlayan ulnar sinir nöropatisi veya artritin yol açtığı ağrı, hareket kısıtlılığı ve fonksiyon kaybı ile başvururlar (Şekil 7). Daha çok ulnar sinir nöropati şikayeti ile başvuran olgularda, eklem rekonstrükte edilemeyecek derecede hasarlı ise, öncelikle ulnar sinirin öne transferi uygulanır. Dirseğin kullanımını engelleyecek derecede ağrısı olan genç olgularda artrodez, ileri yaş olgularda ise artroplasti önerilmektedir.

Dış kondil kaynamamalarında, brakiyoradyalis kası ve el bileğinin radyal taraflı uzun ekstansörlerinin öne, trisepsin lateralinin arkaya doğru kaldırılması ile, dirsek menteşe şeklinde açılarak eklemin ön yüzeyi görünür hale getirilebilir. ${ }^{[7]}$ Eklem devamlılı̆̆nı sağlayan ve genişliğini daraltmayan osteosentez ve gerekirse greftleme yapılır. Dış yan veya arka taraftan kilitli plak veya büyük olmayan kondillerde, kanüllü vidalarla rijid tespit yapılır.

Erişkinlerde, eklem içi kaynamamada dizilimin düzeltilmesi, kollateral bağ gibi yumuşak doku sınırlayıcılarının restorasyonu ve troklea ile olekranon arasındaki ilişkinin tekrar kurulması, dirsekte stabilitenin yeniden elde edilmesini büyük oranda sağlar. Stabilitenin sağlanması ve kaynamanın elde edilmesi, fonksiyonel sonuçların iyileşmesine ve dejeneratif artritin önlenmesine yol açar. Kaynama olmayan olgularda; implant gevşemesi, enfeksiyon ve heterotopik kemikleşme, eklem aralığı daralması ve osteoartrit gibi problemler de birlikte görülmektedir (Şekil 8).

Her iki kondilin kaynamadığı durumlarda da; posterior yaklaşım ve olekranon osteotomisi ile kaynamama hattının debridmanı, eklem yüzeyinin daraltılmadan rekonstrüksiyonu, otojen greftleme, anterior ve posterior kapsülektomi ve ulnar nöroliz önerilmektedir.
McKee, $43^{\circ}$ ortalama eklem hareket açıklığı ve $45^{\circ}$ fleksiyon kontraktürü olan, beşi kaynamama, ikisi kaynama ve ikisi yanlış kaynama olan olgularda iyi sonuç elde etmiştir. Ortalama 13,4 ay sonra tedavi ettiği olgularında $97^{\circ}$ eklem hareket açıklığı sağlanmıştır. Dejeneratif artrit gelişmeyen olgularında olan dokuz ulnar sinir lezyonu da düzelmiştir. ${ }^{[9]}$ Ackerman, eklem içi kaynamama veya ciddi yumuşak doku travmasının birlikte olmasını kötü prognostik faktör olarak bildirmiştir. ${ }^{[10]}$

Jupiter'in, ortalama yaşı 39,7 olan 13 hastasının yedisinde eklem içi yanlış dizilimli kaynamama vardır. Ameliyat öncesi ulnar nöropatisi olan dokuz hastanın dirseğinde, ortalama $43^{\circ}$ eklem hareket açıklığı ve $45^{\circ}$ fleksiyon kontraktürü tespit etmiştir. Dirsek rekonstrüksiyonları asıl yaralanmadan ortalama 13,4 ay sonra yapılan olguların tamamında kaynama sağlanmıştır. Ortalama $97^{\circ}$ eklem hareket açıklığı ile birlikte iki mükemmel, sekiz iyi ve üç orta Mayo dirsek performans indeksine ulaşılmıştır. ${ }^{[7]}$

Humerus iç epikondil kaynamamaları, akut kırıkların cerrahi dışı tedavileri sonrası gelişebilir. Kırık parçalarının arasında belirgin açıklık olsa da, fibröz kaynama dokusu küçük parçaların mediyal kondile tutunmasını sağlar ve ulnar nörite yol açmamışsa fonksiyonlar normale yakındır. Epikondil ile kondil arasında kemik kaynaması elde edilmeye çalışılmaz; ulnar sinirin gevşetilmesi ve öne taşınması ile ekstansör kasların ortak başlangıcından kemik parçalarının eksizyonu yeterlidir. Eğer kırık kaynamaması uzun süreli ise, bu kasların serbestleştirilmesi ve erimeyen sütürlerle iç kondile tespit edilmesi gerekmektedir. İç kollateral bağ yaralanması olan olgularda, tendon grefti ile bağ rekonstrüksiyonu yapılır (Şekil 9).

\section{Kapitellar ve troklear kaynamama}

Kapitellum ve troklea kırıklarında, eklemde birden fazla parça ve posterior parçalanma varlığı, kaynamamaya eğilimi gösterir. (Şekil 10. a, b) Brouwer, troklea ve kapitellum parçalı kırı̆ı ı ve posterior parçalanması olan 18 hastanın 8'inde kaynamama bildirmiştir. Anteriorda büyük tek parçalı kırığa posterior parçalanma eşlik eden veya etmeyen olgularda ise tam kaynama elde etmiştir. Kapitellum ve trokleanın beslenmesi, asıl olarak arka taraftan, kondillere giren damarlarla olmaktadır. Kırık esnasında posterior parçalanma, dış kolonun damarlanmasını bozarak kırığı kaynamamaya yatkın hale getirmektedir. ${ }^{[8]}$

\section{Protez ile replasman}

İnternal tespit için uygun olmayan osteopenik kemik ve osteojenik potansiyeli kötü, fonksiyonel talebi az olan yaşlı hastaların distal humerus kırıkları ve 

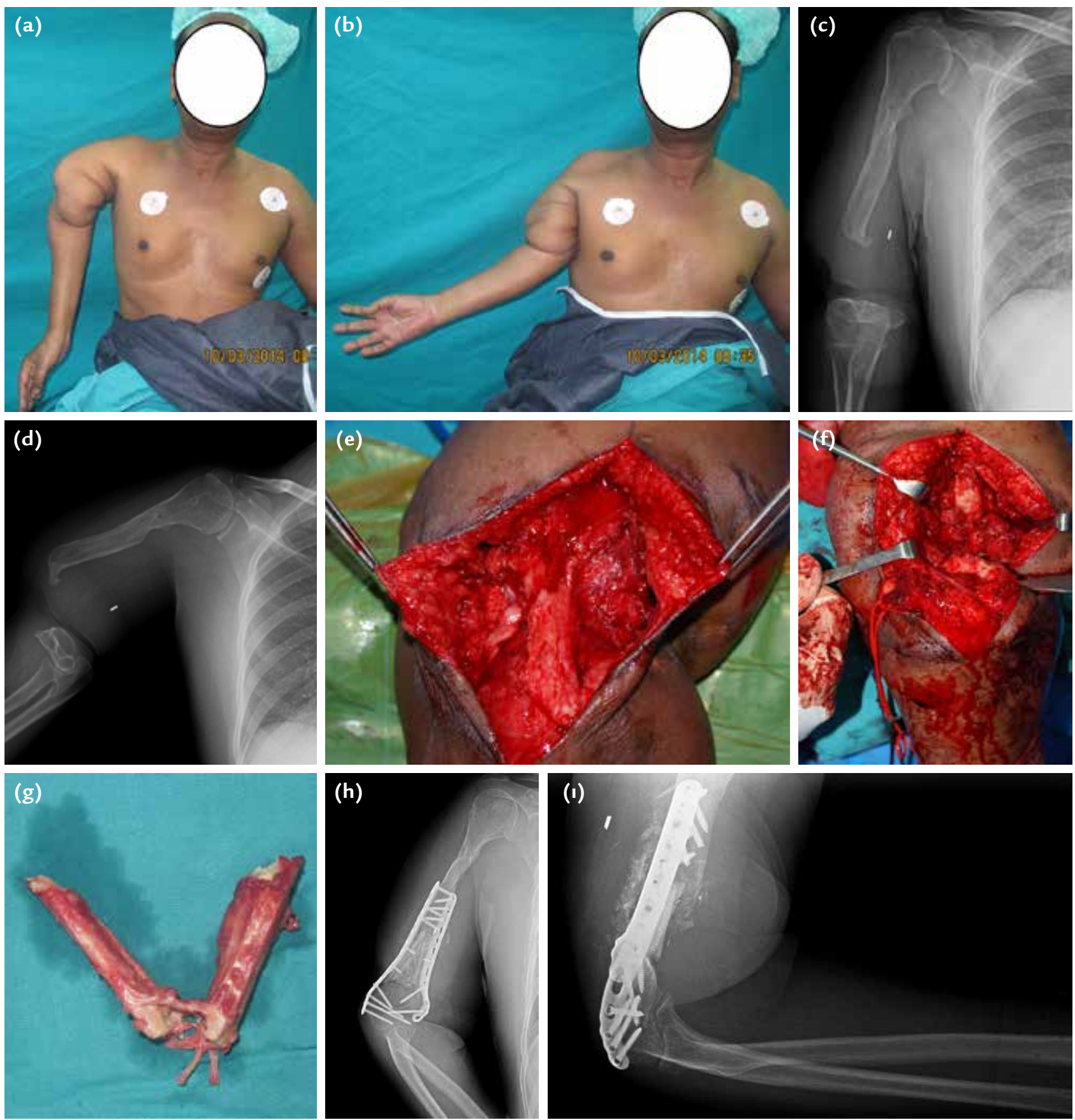

Şekil 6. a-g. Ateşli silah ile yaralanan 54 yaşında erkek hasta, sonuncusu sekiz yıl önce olan beş ameliyat geçirmiştir. Dirsek hareketi kaynamama hattından olmaktadır $(\mathbf{a}, \mathbf{b})$. Ön arka ve yan humerus radyografisinde uzun bir kemik kaybı ile birlikte olan suprakondiller humerus kaynamaması görülmektedir; humerus distali oldukça kısadır (c, d). Eski posterior insizyonu kullanılarak girişim yapılan olguda triseps distalinin incelmiş olduğu tespit edilmiştir (e). Kaynamama alanında yapılan debridman sonrası humerus distalinde defekt alanı görülmektedir (f). Sol bacağından alınan damarlı fibula kemik grefti periost korunarak ortadan ikiye kesildi. İç ve dış kolonu oluşturmak üzere ters ' $V$ ' şeklinde humerus distaline yerleştirilen fibulanın kaynadığı ön-arka ve yan radyografilerde görülmektedir (g). 

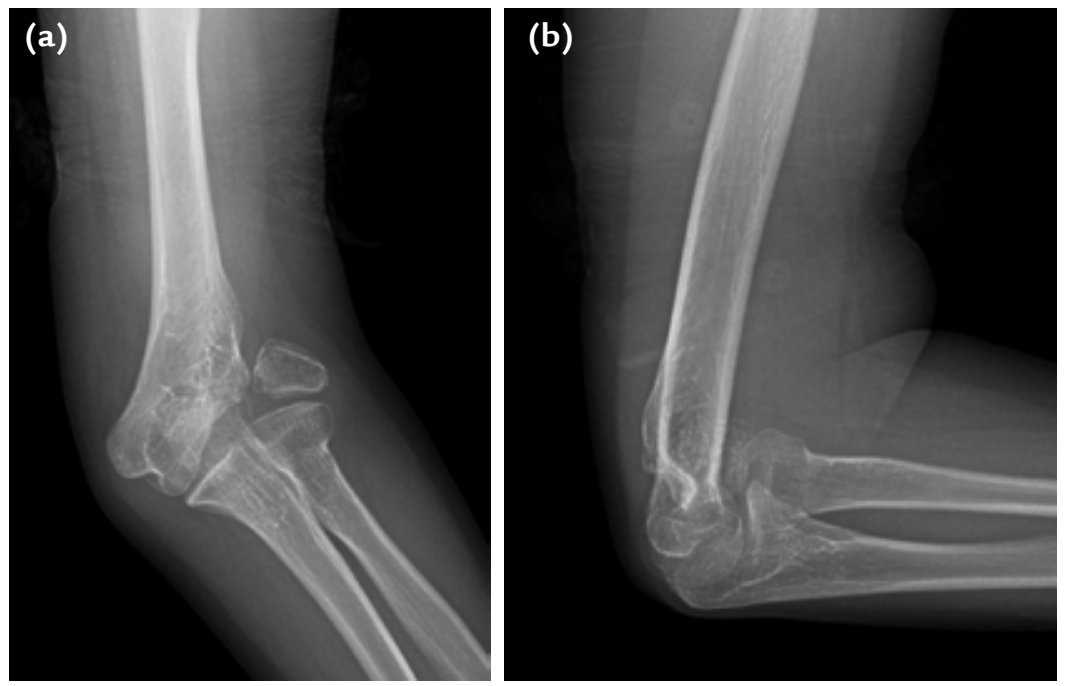

Şekil 7. a, b. Yirmi yaşındaki kadın hastada, çocukluk çağında geçirmiş olduğu dış kondil kırığına bağlı küçülmüş ve düzleşmiş dış kondilin kaynamaması. Radius başında yuvarlaklaşma ve genişleme ile dirsekte kubitus valgus deformitesinin olduğu ön-arka (a) ve yan (b) radyografilerde görülmektedir.
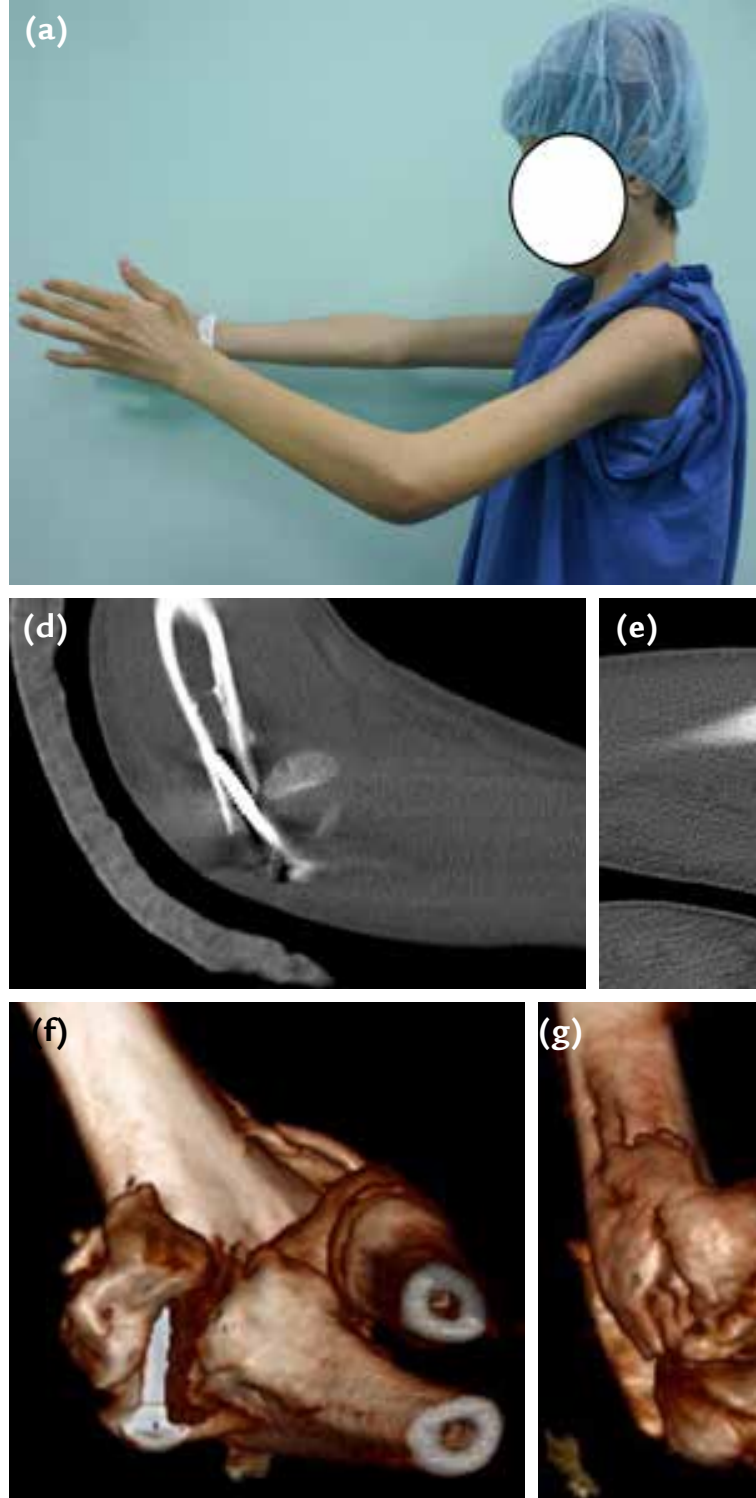
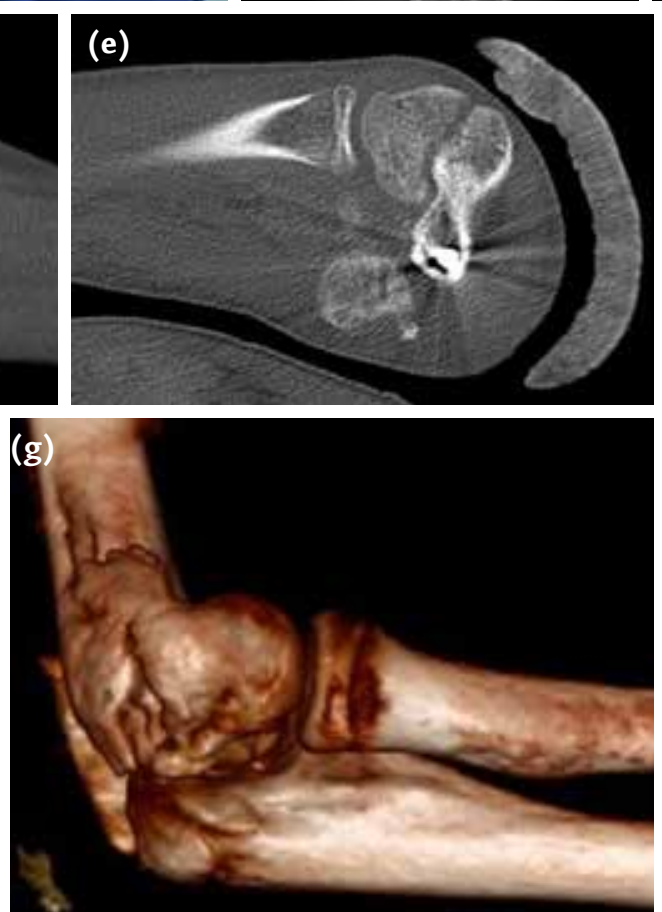

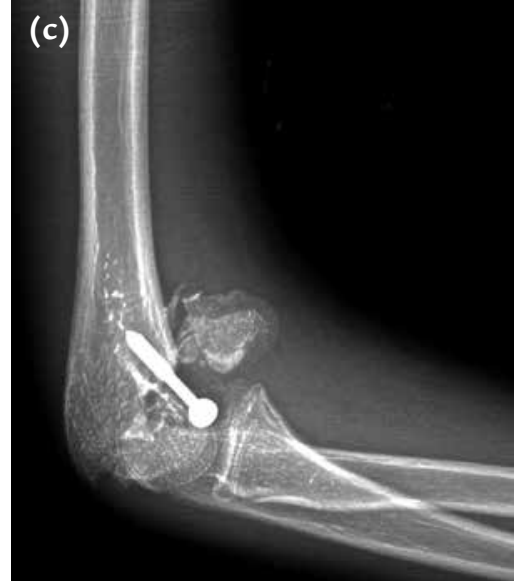

Şekil 8. a-g. Dört ay önce sol dirsek üzerine yüksekten düşme sonrası iç kondile vida ile dış kondile K-telleri ile osteosentez yapılmış. Dirseği $30^{\circ}$ sabit pozisyonda duran hastanın sol el birinci aralıkta (web) atrofi, parmaklarda ulnar sinire uyan duyu ve adduksiyon kaybı (a) tespit edildi. Ön-arka ve yan radyografi $(b, c)$, BT (d, e) ve üç boyutlu tomografide ( $f$, g) iç kondilin öne yukarıya doğru vidadan sıyrılarak kaynamadığı ve dış kondilin yanlış pozisyonda kaynadığı tespit edildi. 

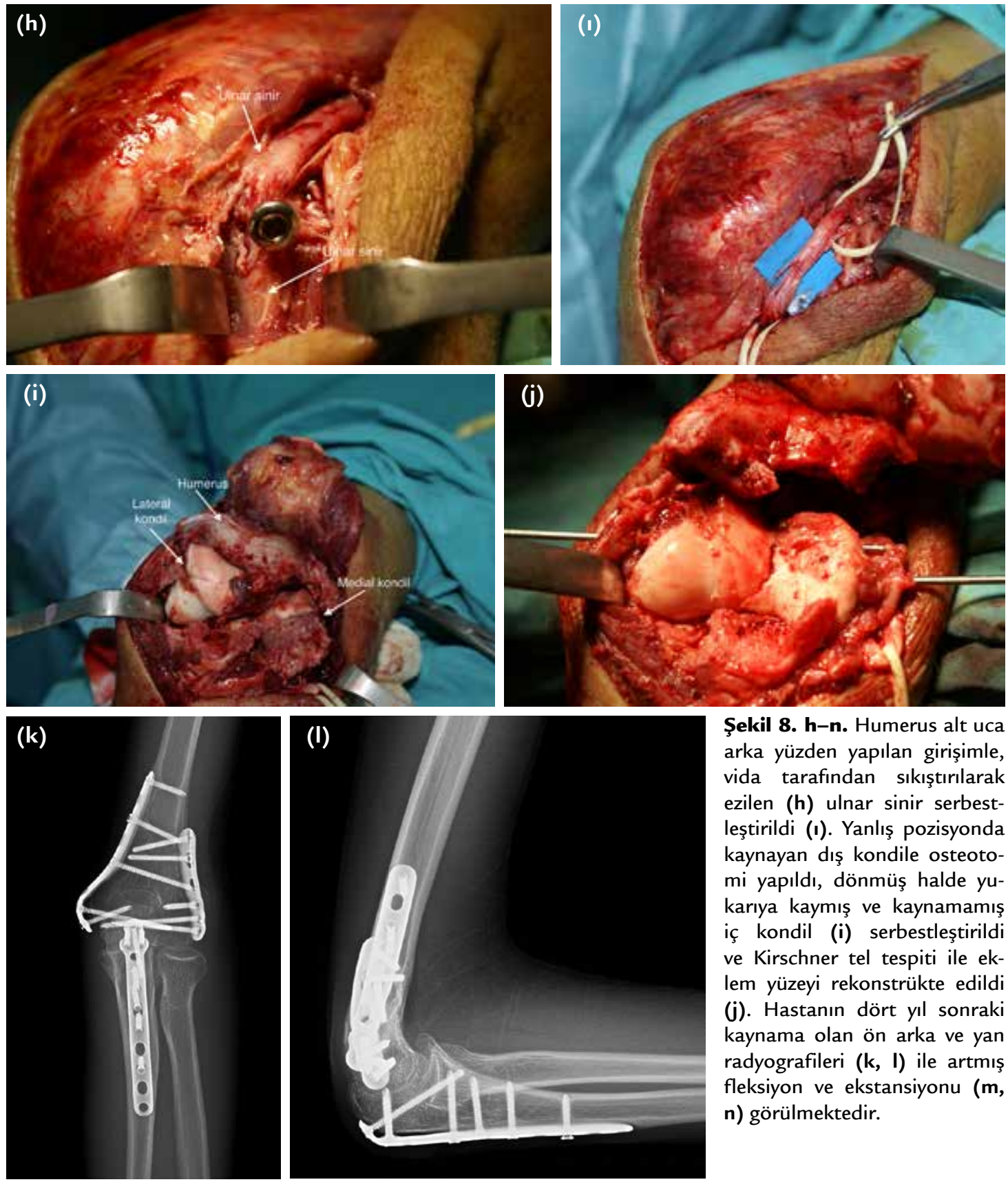

Şekil 8. h-n. Humerus alt uca arka yüzden yapılan girişimle, vida tarafından sıkıştırılarak ezilen (h) ulnar sinir serbestleştirildi ( 1 ). Yanlış pozisyonda kaynayan dış kondile osteotomi yapıldı, dönmüş halde yukarıya kaymış ve kaynamamış iç kondil (i) serbestleştirildi ve Kirschner tel tespiti ile eklem yüzeyi rekonstrükte edildi (j). Hastanın dört yıl sonraki kaynama olan ön arka ve yan radyografileri $(k, I)$ ile artmış fleksiyon ve ekstansiyonu ( $\mathrm{m}$, n) görülmektedir.
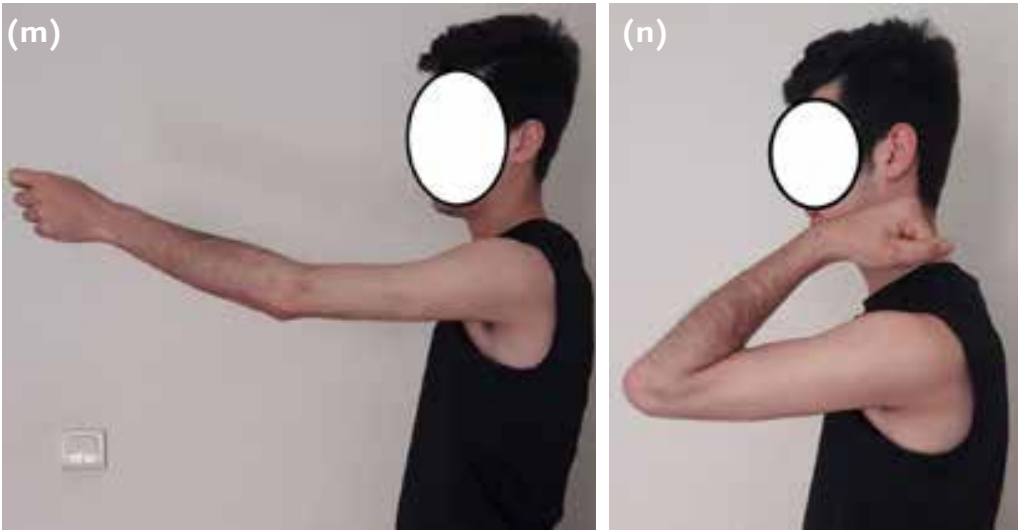

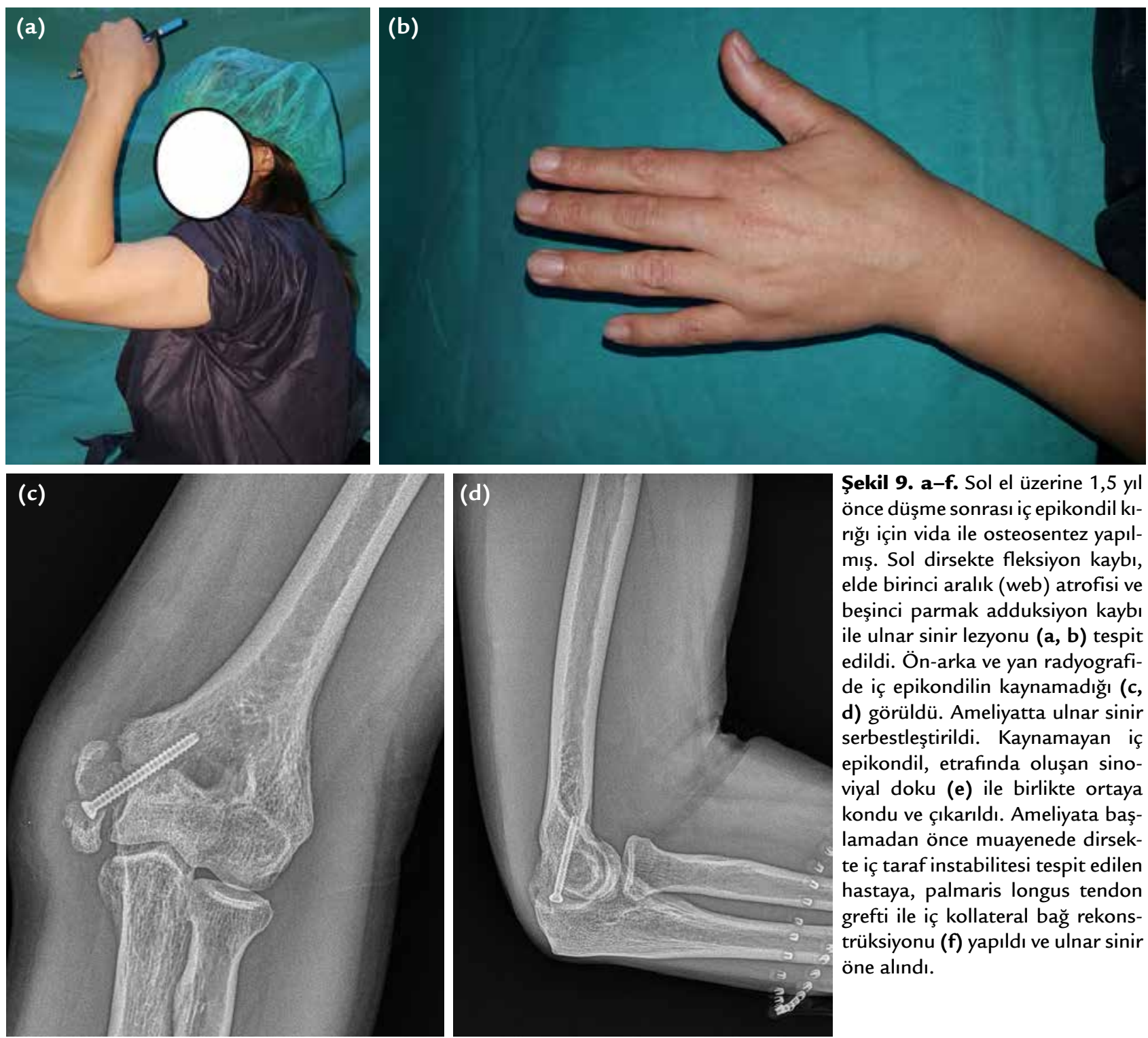

Şekil 9. a-f. Sol el üzerine 1,5 yıl önce düşme sonrası iç epikondil kırığı için vida ile osteosentez yapılmış. Sol dirsekte fleksiyon kaybı, elde birinci aralık (web) atrofisi ve beşinci parmak adduksiyon kaybı ile ulnar sinir lezyonu (a, b) tespit edildi. Ön-arka ve yan radyografide iç epikondilin kaynamadığı (c, d) görüldü. Ameliyatta ulnar sinir serbestleştirildi. Kaynamayan iç epikondil, etrafinda oluşan sinoviyal doku (e) ile birlikte ortaya kondu ve çıkarıldı. Ameliyata başlamadan önce muayenede dirsekte iç taraf instabilitesi tespit edilen hastaya, palmaris longus tendon grefti ile iç kollateral bağ rekonstrüksiyonu (f) yapıldı ve ulnar sinir öne alındı.
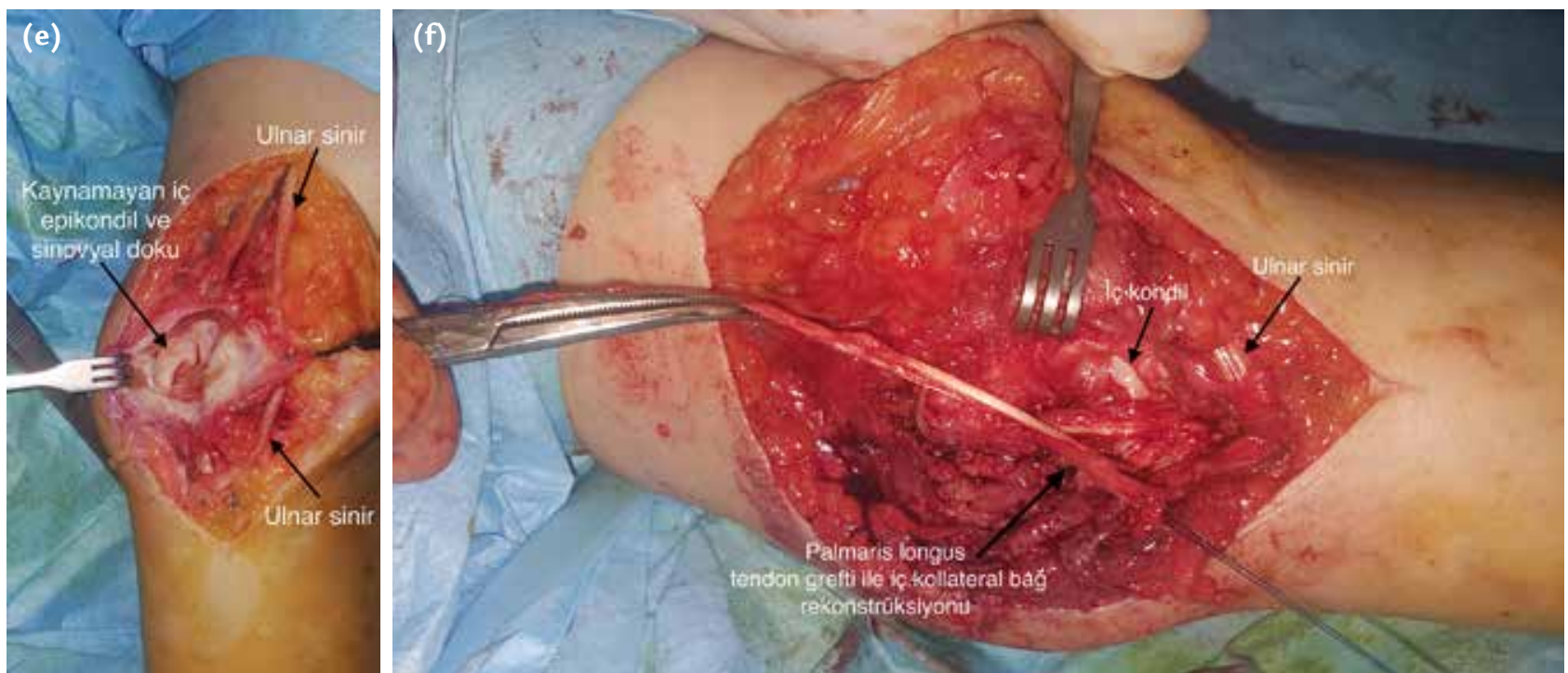

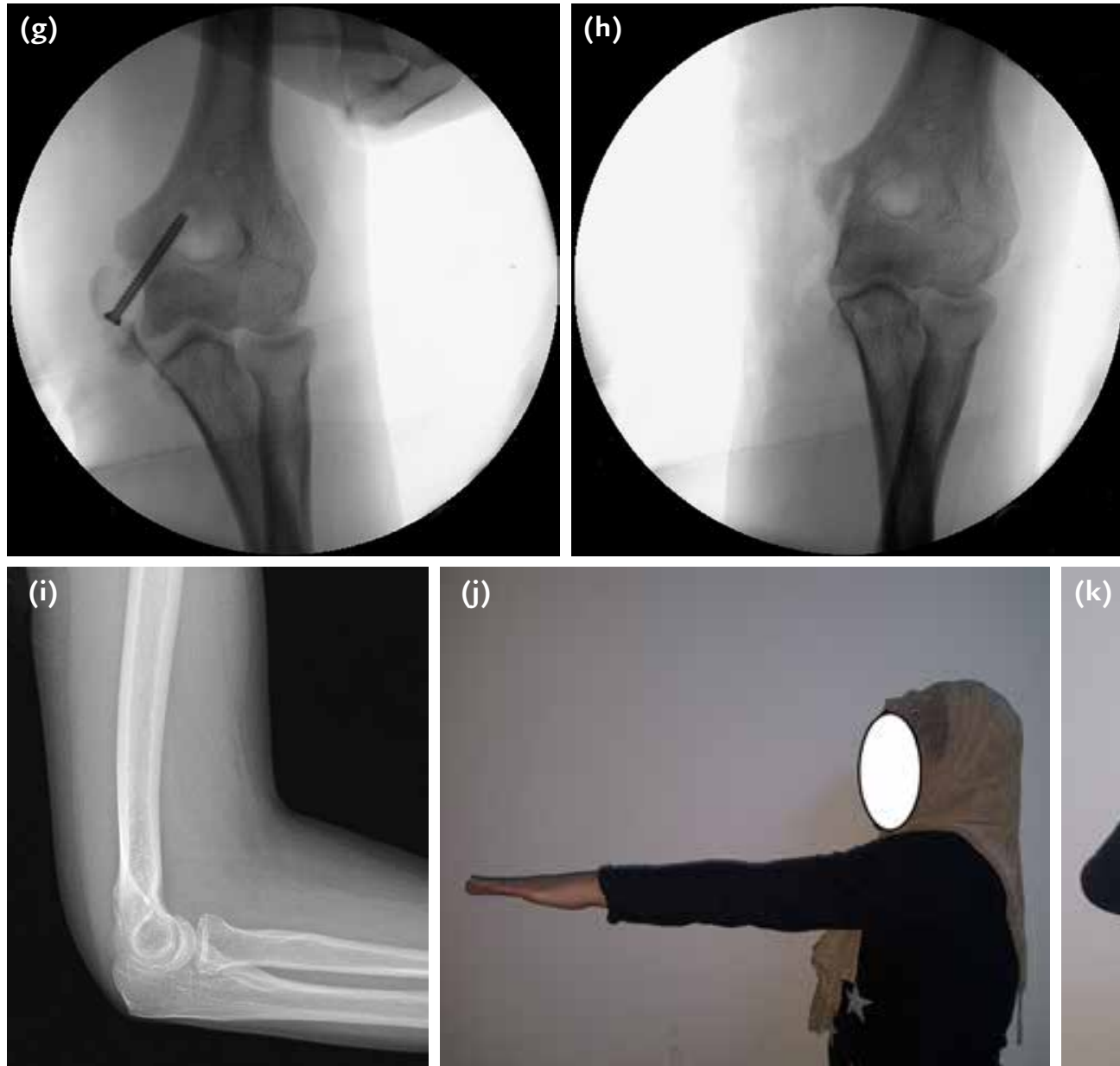

$(\mathrm{k})$

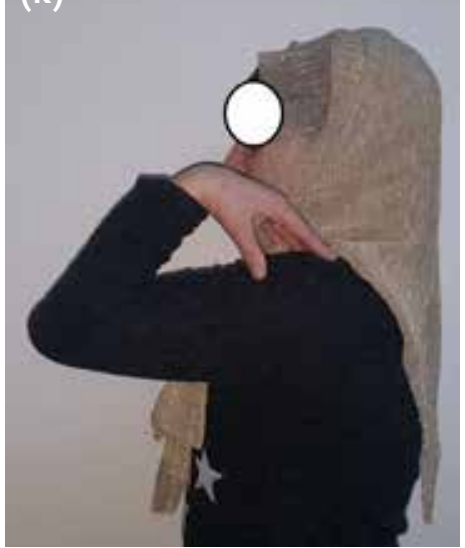

Şekil 9. g-k. Ameliyata başlamadan önce floroskopide valgus yüklenmesi ile ulnotroklear aralık açılan (g) dirseğin bağ rekonstrüksiyonu sonrası valgus yüklenmesinde stabil olduğu (h) tespit edildi. Bağ rekonstrüksiyonu yapılan hastanın ameliyat sonrası radyografisi $(\mathbf{\imath}, \mathbf{i})$ ve fleksiyon ve ekstansiyon hareketinin arttığı $(\mathbf{j}, \mathbf{k})$ görülmektedir.
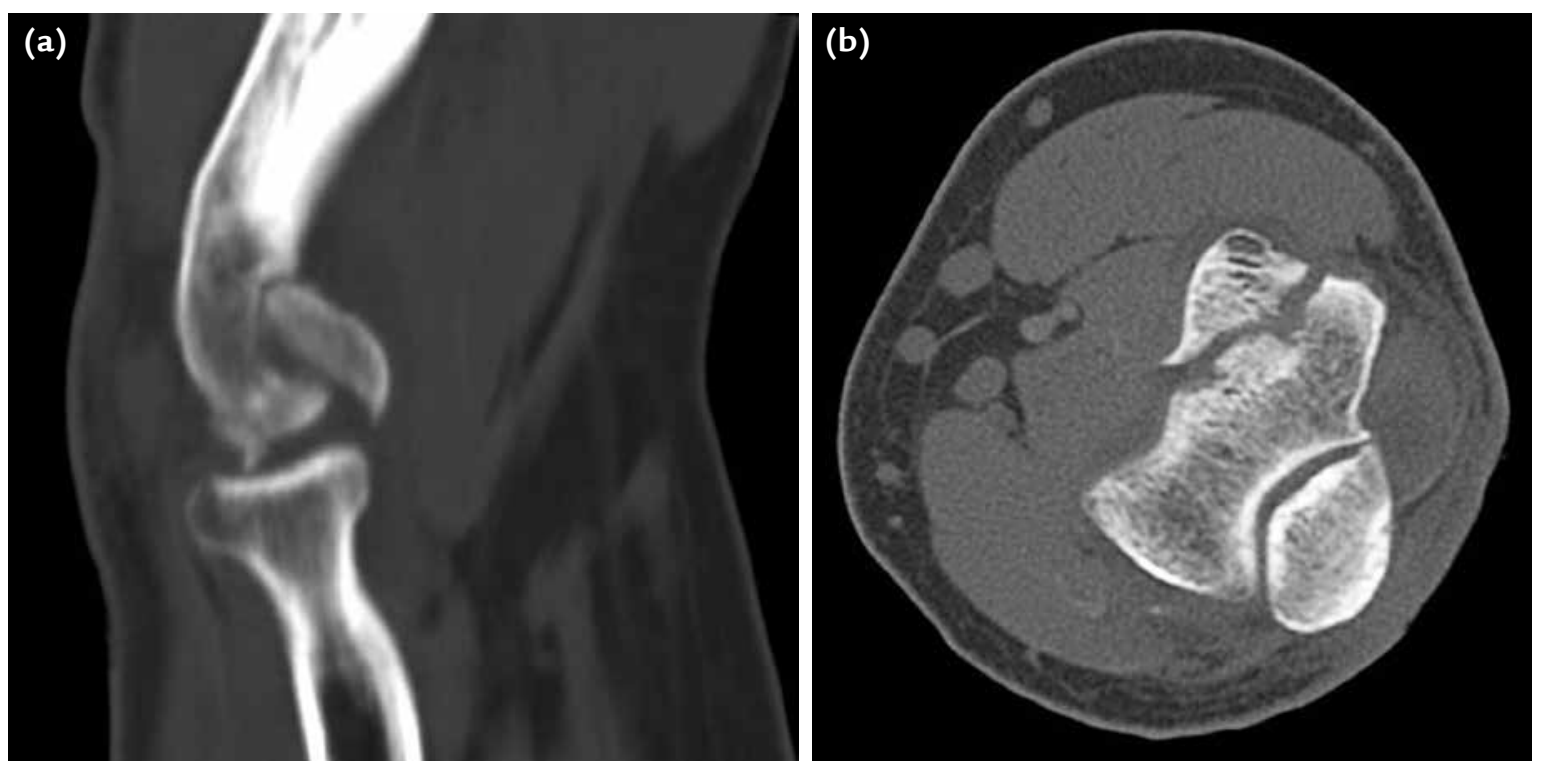

Şekil 10. a, b. Kapitellumda kaynamayan parça ve arkasında eklem yüzünde çökme ile birlikte parçalanma olan olgunun yan (a) ve aksiyel kesit (b) BT'si görülmektedir. 
kaynamamalarında, dirsek fonksiyonlarının kazanılması için protez replasmanı kurtarıcı işlemdir. Total dirsek protezi uygulamalarında en iyi sonuçlar; 65 yaş üstü, eklemde artroz bulguları olan, kemik stoğu azalmış, eklem yüzeyinde ciddi bir harabiyet ve kemik stoğunun yetersizliği nedeni ile iç tespit uygulanamayacak ve kol fonksiyonlarından düşük beklentisi olan, daha önce sadece tek ameliyat geçirmiş ve enfeksiyonu olmayan hastalarda elde edilmektedir. Total dirsek artroplastisi ile, ağrı giderilir, dirsekte hareket ve fonksiyon restorasyonu sağlanır. ${ }^{[17,25]}$ Çil, distal humerus kaynamadığı için total dirsek artroplastisi yaptığı 91 hastanın 92 dirseğinin 9'unda başarısızlık bildirmiştir. Olguların \%74'ünde ağrı yoktur veya hafif bir ağrı vardır. Artroplastiden önce ekstansiyon ortalama $37^{\circ}\left(-5^{\circ}\right.$ ile $90^{\circ}$ aralı̆ğnda), fleksiyon $106^{\circ}\left(30^{\circ}\right.$ ile $155^{\circ}$ aralığında) iken, artroplasti sonrası ekstansiyon $22^{\circ}\left(0^{\circ}\right.$ ile $90^{\circ}$ aralığında) ve fleksiyon $135^{\circ}\left(60^{\circ}\right.$ ile $170^{\circ}$ aralığında) olarak tespit edilmiştir. Hastaların 77'sinde iyi ve çok iyi, 20'sinde vasat ve kötü sonuç alınmıştır. Dirseklerin kırkında 44 komplikasyon meydana gelmiş ve 32 yeni ameliyat yapılmıştır. Olguların 23'ünde implant revize edilmiş veya çıkarılmıştır. Herhangi bir nedenle implant çıkarılmadan veya revizyonu olmadan protez sağkalım oranı iki yılda $\% 96$, beş yılda \%82 iken, $10-15$ yılda \%65 olarak tespit edilmiştir. Başarısızlık için önemli risk faktörleri; 65 yaşından genç olma, birden fazla olan önceki cerrahi işlemler ve herhangi bir enfeksiyon öyküsüdür. En önemli dezavantajları, kullanılan implantlarla ilişkili komplikasyonlar ve ameliyat sonrası dönemde gevşeme ve aşınma riskini azaltmak için üst ekstremite kullanımının kısıtlanması gerekliliği olarak sayılabilir. ${ }^{[17]}$ Pogliacomi ve ark., protez replasmanını fonksiyonel ihtiyacı düşük ve 70 yaş üstü hastalarda önermektedir. ${ }^{[25]}$

\section{Artrodez}

Artrodez, eklem rekonstrüksiyonu yapılamayacak humerus alt uç kırıkları ve enfeksiyon nedeniyle veya uyum sağlayamayacağı düşünüldüğü için artroplasti düşünülmeyen hastalarda uygun bir tercihtir. ${ }^{[7]}$ Artrodez ayrıca, geri dönüşsüz eklem harabiyeti, kemik kaybı veya enfeksiyonu olan genç ve aktif hastalarda da uygun bir seçenektir. Dirsek artrodezinin, fonksiyonlarda çok ciddi kısıtlamalara yol açacağı göz önünde tutularak, stabil ve ağrısız bir ekstremite elde etmek için uygulanan bir kurtarma girişimi olduğu unutulmamalıdır (Şekil 11). ${ }^{[7,11]}$
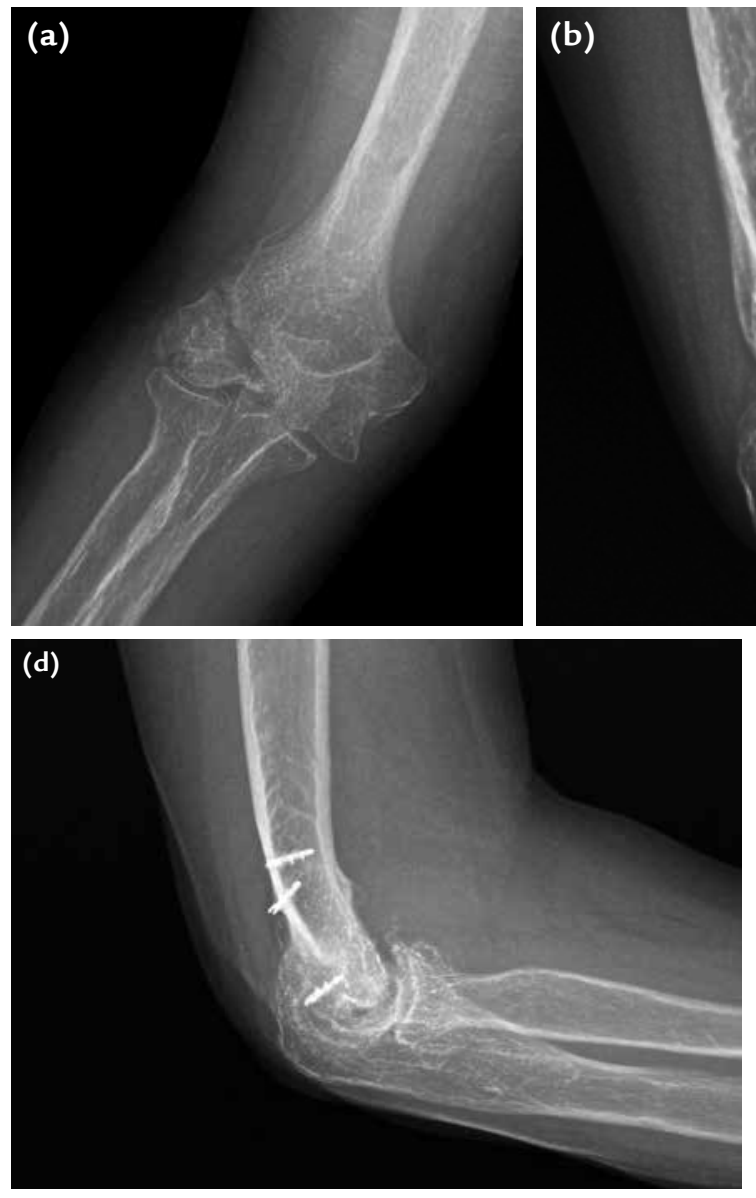

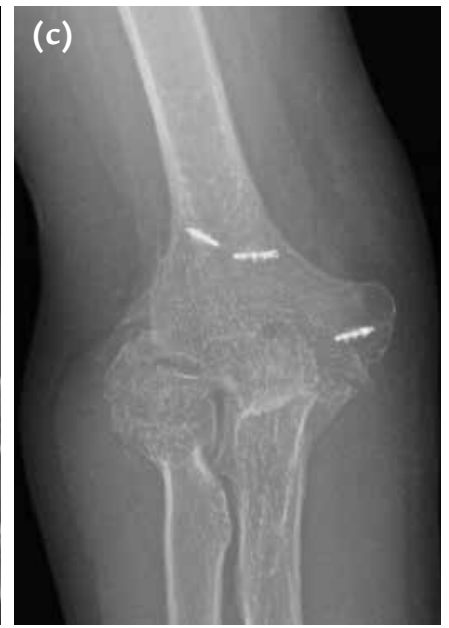

Şekil 11. a-d. Dört yıl önce düşme sonrası humerus alt uçta dış kondil kaynamaması gelişen hastaya (a, b), üçüncü ameliyatında dirsek interpozisyon artroplastisi (c, d) yapılmış direkt radyografisi görülmektedir. 

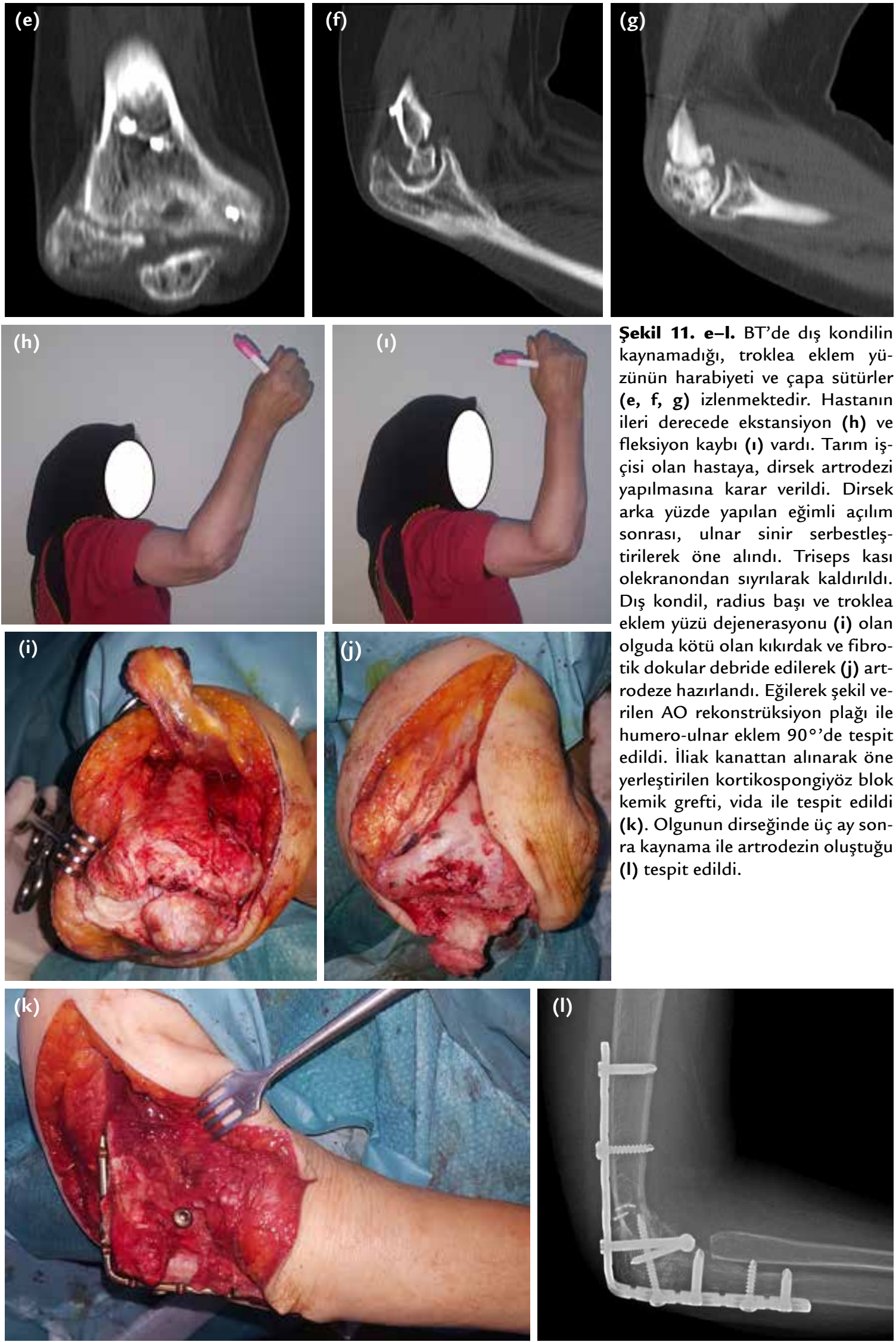


\section{KAYNAKLAR}

1. Sanchez-Sotelo J, Torchia ME, O'Driscoll SW. Complex distal humeral fractures: internal fixation with a principlebased parallel-plate technique. J Bone Joint Surg Am 2007;89(5):961-9. Crossref

2. Ali A, Douglas $H$, Stanley D. Revision surgery for nonunion after early failure of fixation of fractures of the distal humerus. J Bone Joint Surg Br 2005;87(8):1107-10. Crossref

3. Claessen FM, Braun Y, Peters RM, Kolovich GP, Ring D. Plate and Screw Fixation of Bicolumnar Distal Humerus Fractures: Factors Associated With Loosening or Breakage of Implants or Nonunion. J Hand Surg Am 2015;40(10):2045-51. Crossref

4. Korner J, Lill H, Müller LP, Hessmann M, Kopf K, Goldhahn J, Gonschorek O, Josten C, Rommens PM. Distal humerus fractures in elderly patients: results after open reduction and internal fixation. Osteoporos Int 2005;16 Suppl 2:S73-9. Crossref

5. Helfet DL, Kloen P, Anand N, Rosen HS. Open reduction and internal fixation of delayed unions and nonunions of fractures of the distal part of the humerus. J Bone Joint Surg Am 2003;85-A(1):33-40.

6. Kinik $\mathrm{H}$, Atalar $\mathrm{H}$, Mergen $\mathrm{E}$. Management of distal humerus fractures in adults. Arch Orthop Trauma Surg 1999;119(7-8):467-9.

7. Jupiter JB. The management of nonunion and malunion of the distal humerus -a 30-year experience. J Orthop Trauma 2008;22(10):742-50. Crossref

8. Brouwer KM. Jupiter JB, Ring D. Nonunion of Operatively Treated Capitellum and Trochlear Fractures. J Hand Surg Am 2011;36(5):804-7. Crossref

9. McKee $\mathrm{M}$, Jupiter J, Toh $\mathrm{CL}$, Wilson L, Colton $\mathrm{C}$, Karras KK. Reconstruction after malunion and nonunion of intraarticular fractures of the distal humerus. Methods and results in 13 adults. J Bone Joint Surg Br 1994;76(4):614-21.

10. Ackerman G, Jupiter JB. Non-union of fractures of the distal end of the humerus. J Bone Joint Surg Am 1988;70(1):75-83.

11. Pugh DM, McKee MD. Advances in the management of humeral nonunion. J Am Acad Orthop Surg 2003;11(1):48-59.

12. Cha SM, Shin HD. Open reduction and internal fixation for nonunion of extra-articular distal humeral fractures in patients 70 years and older. J Shoulder Elbow Surg 2018;27(1):118-25. Crossref
13. Donders JCE, Lorich DG, Helfet DL, Kloen P. Surgical Technique: Treatment of Distal Humerus Nonunions. HSS J 2017;13(3):282-91. Crossref

14. Sanchez-Sotelo J. Distal humeral nonunion. Instr Course Lect 2009;58:541-8.

15. Ring D, Jupiter JB. Operative treatment of osteochondral non-union of the distal humerus. J Orthop Trauma 2006;20(1):56-9.

16. Mitsunaga MM, Bryan RS, Linscheid RL. Condylar nonunions of the elbow. J Trauma 1982;22(9):787-91.

17. Cil A, Veillette CJ, Sanchez-Sotelo J, Morrey BF. Linked elbow replacement: a salvage procedure for distal humeral nonunion. J Bone Joint Surg Am 2008;90(9):1939-50. Crossref

18. Breen $T$, Gelberman RH, Leffert R, Botte M. Massive allograft replacement of hemiarticular traumatic defects of the elbow. J Hand Surg Am 1988;13(6):900-7. Erratum in: J Hand Surg Am 1989;14(3):582.

19. Morrey BF. Post-traumatic contracture of the elbow. Operative treatment, including distraction arthroplasty. J Bone Joint Surg Am 1990;72(4):601-18.

20. Brinker MR, O'Connor DP, Crouch CC, MehlhoffTL, Bennett JB. Ilizarov treatment of infected nonunions of the distal humerus after failure of internal fixation: an outcomes study. J Orthop Trauma 2007;21(3):178-84. Crossref

21. Ring D, Gulotta L, Jupiter JB. Unstable nonunions of the distal part of the humerus. J Bone Joint Surg Am 2003;85-A(6):1040-6.

22. Sanders RA, Sackett JR. Open reduction and internal fixation of delayed union and nonunion of the distal humerus. J Orthop Trauma 1990;4(3):254-9.

23. Beredjiklian PK, Hotchkiss RN, Athanasian EA, Ramsey ML, Katz MA. Recalcitrant nonunion of the distal humerus: treatment with free vascularized bone grafting. Clin Orthop Relat Res 2005;435:134-9.

24. Toh S, Tsubo K, Nishikawa S, Inoue S, Nakamura R, Harata $\mathrm{S}$. Long-standing nonunion of fractures of the lateral humeral condyle. J Bone Joint Surg Am 2002;84-A(4):593-8.

25. Pogliacomi F, Aliani D, Cavaciocchi M, Corradi M, Ceccarelli F, Rotini R. Total elbow arthroplasty in distal humeral nonunion: clinical and radiographic evaluation after a minimum follow-up of three years. J Shoulder Elbow Surg 2015;24(12):1998-2007. Crossref 